\title{
THEORY AND REALITY IN BANKRUPTCY: THE SPHERICAL CHICKEN*†
}

\author{
Philip Shuchman**
}

\section{INTRODUCTION}

In his paper entitled Financial Markets, Default, and Bankruptcy: The Role of the State Dean William H. Meckling used some principles widely accepted by economists as "an analytical framework within which to clarify issues, identify more precisely the role which bankruptcy plays, and assess the social consequences of alternative legal structures for bankruptcy." 1

Meckling asserts that "the evidence and economic theory strongly support the proposition that any increase (or decrease) in lending costs brought about by changes in the bankruptcy laws will in the long run be passed along to borrowers or potential borrowers." ${ }^{2}$ These propositions are restated in more "economic" terms: "[T]he supply of funds available for any class of credit is virtually perfectly elastic at an interest rate determined by the costs of lending in that market. ..."3

"Costs" are "defined to include alternative lending opportunities," as well as risks and the various expenses of business operation in consumer lending. ${ }^{4}$ Costs are, to some extent, the result of anticipated and actual risks. The risks include default in the form of a petition in bankruptcy. The price of money is a direct function of these costs to the sellers of money. As Meckling puts it, "The higher these costs, the more it will cost individuals to borrow."

\footnotetext{
* A letter that appeared in Science some time ago related that some commercial egg farmers who were having difficulties raising their hens' production called in a theoretical physicist after several agricultural scientists had no success. After a few months this pundit called a meeting and announced that he had solved the problem. He went to the blackboard and began to explain. "Postulate," he said, "a spherical chicken. ..."

$\dagger$ A commentary on Meckling, Financial Markets, Default, and Bankruptcy: The Role of the State, Law \& Contemp. Prob., Autumn 1977, at 13. This paper was originally presented, in a slightly different form, at the Liberty Fund, Inc., Seminar on the Economics of Bankruptcy at the Law and Economics Center of the University of Miami School of Law (March 31-April 1, 1977)...Ed

** Professor of Law, University of Connecticut. Formerly Deputy Director, Commission on the Bankruptcy Laws of the United States.

1. Meckling, Financial Markets, Default, and Bankruptcy: The Role of the State, LAw \& ConTEMP. Prob., Autumn 1977, at 13.

2. Id. at 21 .

3. Id.

4. Id.

5. Id. at 22 .
} 
Meckling appears to speak unequivocally: "Returns on financial claims are positively related to risk. So far as I am aware, economists have never found a single exception of any consequence to that proposition." 6

All the actions of firms and individuals and all the choices they make are free and can be accounted for by analysis of "the costs and benefits [debits and credits in this rather narrow hedonic calculus] of alternative courses of action."7 It follows, therefore, as regards natural persons, that changes in bankruptcy law which lower the costs of bankruptcy or raise the benefits to insolvent debtors will directly increase the number of debtors who opt for bankruptcy instead of paying their debts.

That part of the vast panoply of creditor-debtor law which we think of as the boundary condition, legal insolvency and bankruptcy, is reducible to a supply and demand curve. The supply of money for lending is a direct function of return. Hence the greater the lenders' costs, the less money will be loaned. Alternatively, matters will continue if the equilibrium can be maintained by passing the increased costs on to the borrowers.

On the debtor's side, if the consequences of bankruptcy are less onerous, less costly, then more of the consumers and business firms who borrow will elect bankruptcy. This will increase the cost of money. Hence any changes that make bankruptcy less unattractive will be self-defeating. All of us in our capacities as borrowers will have to pay more; the increased costs will be imposed upon us or there will be less money available. ${ }^{8}$

It seems to me that the rest of Meckling's paper is largely a commentary on these propositions, an annotation of these economic laws with some illustrative instances.

Meckling uses two examples of changes in the bankruptcy law to illustrate his theses: (1) the proposed elimination of the fraud exception in consumer bankruptcy, by means of which a personal bankrupt who has obtained credit on the basis of a materially false application or other written statement can be denied a discharge of that debt; ${ }^{9}$ (2) the proposed limitations on reaffirmation of debts discharged in bankruptcy. ${ }^{10}$

In much of this paper I will question whether we have enough knowledge

6. Id. at n. 20 .

7. Id. at 25 .

8. See id. at 23 .

9. For this exception see 11 U.S.C. $\$ 35(\mathrm{a})(2)$ (1970). The Commission on the Bankruptcy Laws of the United States proposed in its draft bill that a false financial statement by a consumer debtor should not be the basis for an exception to the discharge of a particular debt. See REPORT of the Commission on the Bankruptcy Laws of the United States, H.R. Doc. 137, 93d Cong., lst Sess. pt. 1, at 176 (1973) [hereinafter cited as Bankruptcy RePort]. (Past and present practice is more fully explained in note 53 , infra).

10. A discharge under the proposed Bankruptcy Act of the Commission on the Bankruptcy Laws would extinguish a scheduled and dischargeable debt. No such debt could be revived or otherwise legally enforced. See Bankruptcy REPORT, supra note 9, pt. 2, § 4-507, at 142. 
to make reasonably accurate predictions of what will happen as a result of these and other changes in bankruptcy law (and creditor-debtor law) by legislation or by appellate-court decision. We have insufficient empirical information. Most of what we know as fact involves extreme situations. And we are often unaware of what the extreme conditions are until we are confronted with dramatic consequences. Hence I will contend that within the usual range of changes made by the Congress, the state legislatures, and the appellate courts, we cannot predict using the model that Meckling proposes and to which many other economists subscribe, more or less. I will give some examples that suggest results in the money market not consistent with these economic theories.

\section{I \\ Theoretical Considerations}

\section{A. Models and Predictions}

The heuristic models used by economists may be useful for many purposes of legal research into bankruptcy law. Much of my response is in the legal form of a demurrer which, however, poses questions in epistemology. Even accepting for purposes of discussion that these economic theories will explain known phenomena within their domain and will predict with reasonable accuracy the impact of known changes in the legal model, still these theories are of limited help in the legislative and rulemaking processes for bankruptcy law for several reasons.

1. We do not know much of the effects of existing laws. In most areas of creditor-debtor law, and of bankruptcy law as the boundary condition of those legal relations, we do not have adequate data.

2. The paucity of knowledge about the actual effects of many laws bespeaks the absence of careful efforts to find out and the lack of theories that will predict the impact of most laws.

3. Those great gaps in our understanding and information (that is, the absence of a general theory of law and lack of knowledge of empirical facts) are endemic to legal scholarship.

I will try to illustrate that even given most of the economists' rules (some are theoretical constructs with some empirical verification extrapolated to situations which appear to be part of the same structure-that is, they are based on a coherence theory of truth) some of the empirical realities we do know about indicate (1) that the theories may not be true for all of the money market; (2) that the theories apply sometimes, but we do not necessarily know when they do and do not; (3) that we do not know enough of the effects of existing or changed laws ${ }^{11}$ to know when the economic theories will or would

11. This is to state the experimental posture of American legal realism that it is necessary to distinguish the positive law from its implementation and effects in practice. 
apply to explain and predict; and (4) that we do not usually know enough of these realities to say whether the theories are general.

Meckling states that "[b]ankruptcy is, after all, only one feature of a larger system, the financial system." 12 That may be an accurate statement only within his perceptual model. But I doubt that a financial market can even be defined except as part of, and in the context of, a specific legal system. Bankruptcy may also be viewed not only as part of the larger financial system but as part of the larger legal system. That seems more fitting, because there were legally regulated financial markets before there was bankruptcy, and there were financial markets when there was no bankruptcy in the Nation's history. But there are very primitive, if any, financial markets in the absence of a legal system. ${ }^{13}$

\section{B. Models and Observations}

These considerations should be more fully stated, because it seems to me that Meckling wants to make scientific assertions about matters of fact and law but confuses synthetic propositions with analytic propositions and mistakes models for empirical reality, thereby begging some questions that are crucial to any scientific endeavour.

First there must be a theory. Meckling's theory is, as we have seen, that everywhere we look, in particular, at creditor-debtor and bankruptcy law, all changes in costs-here brought about by changes in law designed to benefit consumer-debtors-will result directly and invariably in changes in the lending market which will make the reform self-defeating. This economic law applies as well to natural persons of modest means and large business firms.

Professor Posner, in describing the "new" law-and-economics research, puts it that in this type of research "the legal system is treated as a given and the question studied is how individuals or firms involved in the system react to the incentives that it imparts." Posner, The Economic Approach to Law, 53 TEX. L. REv. 757, 763 (1975).

12. Meckling, supra note 1 , at 17. Dean Meckling feels that the desire of borrowers to assure lenders of repayment is one of the reasons for granting police powers to the state and having a court system: "If government did not exist to play this role, prospective borrowers would undoubtedly find a replacement." Id. at 15 . Perhaps historical accuracy is not intended, but this view of the origin of the various creditors' legal remedies is a construct, a model to account for our organization of the legal system to favor certain kinds of creditors. His comments on the origins of the state's police powers as part of the credit system have an ironic ring. I doubt that most of the historical evidence bears out his view that judicial sanctions for enforcement of creditors' remedies arose from the desires of borrowers. The vital bankruptcy discharge in its earliest forms was, it appears, advocated by creditors who hoped that the discharge would bring about more cooperation from debtors in making full disclosure and delivery of their available property for the benefit of their creditors. See J. Maclachlan, Bankruptcy 88 (1956). The discharge was from imprisonment for debts; the debts remained.

13. Bankruptcy laws are as much a part of the monetary system as are dollar bills. Economies with different financial laws differ from each other much in the same way as geometries based on different axiom systems differ from each other. Money and laws for financial operations form part of the rules of the economic game. When the rules are different, the game is different.

Shubik, A Curmudgeon's Guide to Microeconomics, 8 J. Econ. LIT. 405, 428 (1970). 
Of course, economists do not look everywhere. They must specify which tests of their generalizations and theories are decisive. For not all tests will settle disputes about economic theory, and not all results of tests are dispositive. I add-for it applies to my examples as well as his-that testing in the social sciences is not a straightforward process.

It is not necessary that Meckling's model be more realistic or that his examples for theory be taken from the consumer credit market place. Yet while the major section of his paper theorizes about a money market which involves consumers as well as lending firms, many of his examples do not involve consumer-borrowers as economic agents. Relatively few consumerborrowers "shift ... from deposit forms which have ceilings on interest rates (e.g., savings and checking accounts) to forms which do not (e.g., commercial paper, Treasury bills, certificates of deposit)." ${ }^{14}$ If he is going to use assumptions based on observable phenomena, they should be matters which his theory shows to be part of what the theory covers, what counts as an instance in a theoretical model. I think the more realistic, conforming, and typical the assumptions are, the better a theory is apt to be and the more probably true its predictions. ${ }^{15}$

The difference between prediction and explanation seems blurred in Meckling's account. I take a prediction to be a statement of an instance which a generalization holds will occur. An explanation shows how an instance is included in or covered by a generalization, whether a theory or merely a group of related hypotheses. If the assertions of Dean Meckling and Professor Weston ${ }^{16}$ are predictions, statements of what will happen, they are synthetic but presumably subject to rebuttal by an appropriate test in which the empirical data are known and other possibly causal factors do not change or can be accounted for.

Of course there is a way to avoid the problem. One can, and both Dean Meckling and Professor Weston may have implicitly done so, dismiss nonconforming behavior as irrational, noneconomic actions, not to be considered in their calculus. To the extent that this is true, the actual behavior of firms and individuals in the consumer credit market is not necessarily a proper test of their economic theory.

The basis for their dismissal is a bedrock theoretical assumption that Dean

14. Meckling, supra note 1 , at 20. Most of the persons who so shift have substantial net worth. Such "deposit forms" usually require minimum amounts beyond the means of all but a small segment of the population.

15. But see M. Friedman, The Methodology of Positive Economics in Essays in Positive EconomIcs 3, 14 (1953) [hereinafter cited as Friedman]. Professor Friedman's analogy with physics may be ill-considered. It does not seem consistently true of the past 25 years of physics that less realistic assumptions constitute the bases for better theories in physics. Part of the problem may be what counts for "realistic." How does one measure that quality in physics?

16. See Weston, Some Economic Fundamentals for an Analysis of Bankruptcy, LAW \& ConTEMP. Pros., Autumn 1977, at 47. 
Meckling and Professor Weston share: that individuals and firms engaged in consumer credit transactions always act as profit maximizers. It is unclear to me whether that is a description of actions or a statement about the intentions of borrowers and lenders. ${ }^{17}$ It does make a considerable difference which it is for the manner in which we could test predictions based upon their assumption. This premise is helpful, perhaps essential, in looking at the rather narrow world of economically purposive actions. It yields good results more often than any other theory about a wider range of economic behavior, and it corresponds to more of our personal experience of other persons and businesses. Yet this assumption also gives us an image of consumers running to the lender who offers the cheapest rate, and lender firms hustling to get the most out of each loan and always seeking out new types of loans with potentially greater yield. The assumption also gives us a model in which, to the extent that bankruptcy is made less unattractive, larger numbers of distressed consumer-borrowers will file in bankruptcy. ${ }^{18}$

I think such statements about the elasticity of supply and demand are analytic and empty of content. These statements are correct by definition. They do not predict ${ }^{19}$ and they are not to be rebutted. If, for example, the costs of bankruptcy to the petitioner are reduced, and yet the use of bankruptcy does not increase, that means that the elasticity of demand had some negative value (or that it might have had its "true" positive value had not other factors interfered). If bankruptcy is made less costly to petitioners but lenders continue to lend at the same levels and rates, that may show the same sort of thing, although it is a different kind of proposition with additional steps. But these notions result from our definitions and the theoretical structure in which

17. Meckling, although perhaps a secret philosopher, does not intend to be the strict positivist. His language seems to accept implicitly that lending firms act purposively and always in such a manner as to maximize profit. These actions must take into account rate of return and risk, as well as other factors not always relevant. And, I take it, Dean Meckling's views are not conditional in the sense that irrespective of actual (organizational or individual) intent, the lending "firms behave as if they were seeking rationally to maximize their expected returns and had full knowledge of the data needed to succeed in this attempt." Friedman, supra note 15, at 21 (Emphasis added).

18. Debtors, Meckling asserts, "will repay only if default is, on balance, less attractive than repayment. Therefore, the more costly default is to [debtors], the lower is the probability that they will default." Unless the meaning of "less attractive" is broader than legal and economic consequences, I think Meckling's assertion is incorrect as a matter of empirical fact and incomplete because it fails to take into account the many and, I think, often overwhelming noneconomic and nonlegal causes for the legal and economic acts of debt repayment. Meckling, supra, note 1 , at 16 .

19. This is aptly illustrated by the recent and presently continuing disagreement on the elasticity of demand for gasoline. The range of predictions by various economists is, within the likely price increases, from -.4 to +.1 over various periods from immediate one and two-year effects to 10 and 20-year forecasts. (See N.Y. Times, 22 April 1977, § B at 7). But because the statement that there is elasticity of demand is itself empty of content, it is not empirically confirmed or proved to be false. It results in a number which will describe in shorthand manner the recently past behavior of consumers of gasoline. 
they function. ${ }^{20}$ What the statements prove about the empirical realities of behavior or what they can predict is as yet unknown.

If these theories purport to be general, then the existence of possibly rebutting instances, even if not fully analyzed, suggests that the burden is on the theorizer to do one or more of four things:

1. Better analyze what appear to be rebutting instances and data and show that they are irrelevant or not within the theory's domain;

2. Limit or recast the theories so that these are no longer rebutting instances;

3. State the theories only as related hypotheses induced from observations of other parts of the money market and try new experiments and investigations or analyze more past changes (those natural experiments of history);

4. Better analyze the data and show that there were the changes theory would or did predict but that because of other concurrent or simultaneous changes and because our empirical studies are conducted with a coarse net, we missed the changes, because concealed or because too small.

It is, however, the case that for the most part Dean Meckling can be accurate only to the extent that his statements are conditional. If increased legal risk results in continued increased loss, then. . . . But as we do not know whether or when increased legal risk results in more actual risk, and hence in increased loss to lenders, it follows that we do not know when or whether we can apply Dean Meckling's theories. A theory which does not provide for such specification is of very limited use for legislation, rulemaking, and even appellate adjudication of the type which does more than settle a discrete legal controversy between particular parties, that is, sets a precedent.

The constraints of the consumer demand model posited by Meckling (and, to a lesser extent, Professor Weston) are so limiting as to suggest to me that any such theory of consumer behavior is best replaced by a far broader one (or even several) which will use factors such as routine, habits, the costs of and abilities to obtain information, and other behavioral-science findings. ${ }^{21}$ For al-

20. This is because the costs and benefits of bankruptcy as defined by Meckling include psychological variables, such as supposed shame in bankruptcy or pride in contract fulfillment. These costs and benefits also figure in to the "attractiveness" of bankruptcy which cannot be defined independently of the number of debtors bankruptcy actually "attracts." Thus the assumption of elasticity is not threatened by counterexamples. If a legal reform that was supposed to make bankruptcy less unattractive fails to cause more bankruptcies, the economists merely explain that the law didn't make bankruptcy less unattractive. Their assumption that debtors respond rationally to the costs and benefits of bankruptcy is thereby preserved; in fact, that assumption is the premise on which they rest their conclusion that a failure to bring about more bankruptcies indicates a failure to make bankruptcy more attractive. The cost-benefit calculus thus suffers from the same circularity as all hedonic calculi: it shows how agents respond to costs and benefits, but cannot define costs and benefits without reference to the agents' response.

21. See Shubik, supra note 13, at 423. 
though the present level of knowledge in these areas may be tentative and uncertain, yet to dismiss them is to be unable to look fairly at this part of the world of economic actions.

\section{II}

\section{THE LAWYeR's View}

Lawyers and economists tend to view the bankruptcy system differently. Lawyers view bankruptcy, at least when there are assets, as properly concerned with the equitable treatment of creditors when the debtor's (usually liquidated) assets are insufficient to pay all of his creditors in full. That is, lawyers are concerned with the distributive aspects of bankruptcy. Economists tend to concentrate on the allocative impact of bankruptcy. Thus, for economists bankruptcy is but another aspect of the money market mechanisms. Lawyers are concerned with equity and distribution issues which affect creditors and debtors. Also, lawyers (and the Congress) are very much concerned with rehabilitating the bankrupt and giving him a fresh start unencumbered by debts which he cannot hope to repay, or could repay only at great social cost. Even the exempt property, which (next to the discharge) is the most important aspect of the proceeding to the bankrupt and his family, is an equity problem, a matter of social morality.

Part of what appears here is that equitable treatment of the bankrupt and equitable distribution to creditors may be inconsistent with what economists view as efficient reallocation. Or it may be that lawyers and economists are not disagreeing but are talking about incommensurables. It is like the Genesis account of the Creation which should not be regarded as logically incompatible with geology or archeology. ${ }^{22}$ There may not be anything for us to argue about. Our differences may be illusory, because we live in different universes of discourse.

The bills pending before the Congress are intended to be long-run changes in our bankruptcy law, but that may be due to the way lawyers and legislators think about such matters. Lawyers talk of timeless principles. Our pedagogical devices-casebooks-often start with opinions written centuries ago. Our notion of research is mostly to read what some judge wrote last year, or decades or generations back. We look to the past, and for many purposes that is desirable. But our aim is a law that will work (more accurately, appears to work from the reports of litigated cases that arise under it) ${ }^{23}$ for a long

22. See Watkins, Against "Normal Science", in Criticism and the Growth of KNowledge 25, 36 (1. Lakatos \& A. Musgrave eds. 1974).

23. This caveat requires some explanation. Of the 200,000 or so personal bankruptcies a year (since the 1960's) perhaps a few hundred result in what lawyers term a reported case, one in which the facts are given and an explanation of the decision is stated. There are many reasons for this attrition: Most bankruptcies are routine; the relatively few that involve legal questions are mostly settled out of court; personal bankruptcies do not involve enough money for appeals to be 
time.

While serving on the Bankruptcy Commission staff I suggested such barbarisms as a bankruptcy law that would expire in ten or twenty years. Also it seemed evident that a substantial number of personal bankruptcies could be prevented by comprehensive medical insurance. But although such a plan might have had a great impact, it was beyond our jurisdiction. We were to revise the bankruptcy law. This suggests that legal categories are often undesirable because too constricting; also, that consumer credit firms (and economists) would do well to examine some correlates of personal bankruptcy in addition to, or perhaps even instead of, considering whether to make bankruptcy more costly for individuals.

\section{NONBUSINESS B ANKRUPTCY}

\section{A. Theory of the Firm}

Meckling's quotation from my Attempt at a "Philosophy of Bankruptcy"24 is distorted because out of context, and his restatement of what I said is incorrect. $^{25}$

First, my language refers to the employees of lending firms. ${ }^{26}$ Second, it refers to firms in the business of lending money, and especially to those selling money in specialized markets, such as various types of consumer credit. Third, the passage states a concern of those engaged in research on theory of the firm that the interests of employees may be inconsistent with those of the firm and its owners. Finally, that this disparity may not be manifest. For example, the return to investors may not be maximized by the employees, but this will not be found out or the return may still be better than other alternatives.

worthwhile; and so forth. Even when a bankruptcy judge or federal district judge does take the time and trouble to write an opinion, the opinion is usually not published. I guess that a very small fraction of one percent of personal bankruptcies result in reported cases.

Given that background, there is a splendid example of nonknowledge within our subject matter. In a 1960 article discussing, in part, a 1938 amendment to the Bankruptcy Act, it is said that "the total reported impact of the amendment in bankruptcy proceedings is in four cases." Countryman, For a New Exemption Policy in Bankruptcy, 14 Rutgers L. Rev. 678, 745 (1960). The writer has explicitly stated the limits of his knowledge and does not presume to speak of anything other than the number of reported cases on this narrow subject. But his candor does not make the information useful unless there are unstated premises regarding the relationships of degree and kind between the reported cases and other realities.

24. Meckling, supra note 1, at 20, quoting Shuchman, An Attempt at a "Philosophy of Bankruptcy", 21 U.C.L.A. L. REv. 403, 426 (1973).

25. Meckling's partial and somewhat misleading quotation is that "[F]or many lenders . . lending is the only game in town." My reference here was to employees of firms in the consumer credit business. For the complete context see Shuchman, supra note 24 , at 425.

26. See the words "lender (as employee)" immediately preceding the passage quoted. Id. at 426. 
Firms will look to greater profits, ${ }^{27}$ but, through their employees, they also look to other forms of utility not directly associated with return. It seems too narrow a view to say that the firm will seek to maximize profit. There are other aspects of return that are important such as status, the comforts of routine and habit, and the expertise of managers who are influential (in the intrafirm political sense).

Individual and firm responses are not always economically rational. For example, it is hard to show that better public relations has any direct, or even indirect, connection with return. Many firms set their advertising budget as a percentage of sales. Yet in some such cases the more efficient, more rational action might have advertising expenditures inversely related to sales. The assumption of uniform rationality in specific business decisions in specific firms is not, I think, empirically verifiable. There are too many irrational factors. Decisionmaking in business organizations is apt to be the result of a mixture of factors: (1) organizational constraints, (2) intrafirm political forces, and (3) rational bases, as with perceived legal and economic risks and gains. Obviously, in some cases the legal and economic factors will overwhelm other components of decisionmaking. When violation of the outlawed time-price doctrine in Arkansas became a crime, the purchase of chattel paper dropped very sharply. ${ }^{28}$ Professor Benston's example and data from Maine showing the results of a prohibition on renewals and resets of loans by licensed lenders is another example. ${ }^{29}$ But these show us where the boundary condition was.

Even within industries, I doubt that the usual behavior is anything as clear,

27. There may be shifts in the types of loans, and even the types of investments, based in part on anticipated earnings. I didn't address that subject in the article Meckling cites. Nor did I say that "the quantity of funds supplied does not depend on the earnings that lenders realize." Meckling, supra note 1 , at 20.

28. See, e.g., Lynch, Consumer Credit at Ten Per Cent Simple: The Arkansas Case, 1968 U. ILL. L. Forum 592.

29. Benston, An Analysis of Maine's "36 Month Limitation" on Finance Company Small Loans, in 2 National Commission on Consumer Finance, Technical Studies. The data for later years on total installment loans, excluding real estate, indicate that other lenders have taken up the loans formerly made by finance companies. Professor Benston suggested as much (id. at 56), but at his date of publication he had no figures for the years after 1970. The actual numbers of loans are not given, so that Professor Benston's question "whether those who otherwise would have borrowed at finance companies were served by other lenders" (id. at 57) remains largely unanswered except for his finding that in 1970 "half of the borrowers surveyed who previously were considered good customers of the finance companies did not obtain funds when they wanted them." (Id. at 58). Total installment loans in Maine increased from roughly $\$ 393$ million in 1970 to roughly $\$ 656$ million in 1975 . This increase of nearly 170 percent is far greater than the national increase in consumer installment credit. There are other suggestive data. The number of some other lenders' branches increased considerably. The 32 savings banks more than doubled their branch offices from 24 (1970) to 57 (1975); national banks had 103 branches in 1970 and 129 branches in 1975. Per capita installment debt increased significantly in twenty-seven of Maine's twenty-nine economic areas. See Maine Bureau of Banking, Deposit/Loan Distribution by County (July 1976); Maine Bureau of Banking, Deposit/Loan Distribution by Economic Area and Pertinent Data (July 1976) (mimeographed statistical tables available from the office of the Bank Superintendent, Augusta, Me.). 
simple, and unequivocal as Dean Meckling asserts. Rate of return (interest) is not the only critical variable determining investment demand. ${ }^{30}$ Some economists think that changes in the rate of interest bring about proportionately small changes in investment demand. ${ }^{31}$ Even if we assume that increased risk of bankruptcy does in fact result in changes in the per capita extension of consumer credit or its cost, or both, and put aside legal limits such as those on interest rates and security which can be taken, the change in equilibrium may be quite small.

All too often, profit maximization seems to be contradicted as a descriptive hypothesis, although certainly it will be the aim of at least some firms during at least some portion of their history. Even if the direct desire is to maximize return, the effect of that may in many individual cases be overwhelmed by other forces. Too many other considerations can and, I think, do enter into the utility function of a firm. Perhaps profit maximization holds true only as regards probabilistic rules about the behavior over time of large groups of firms. ${ }^{32}$

But, according to Dean Meckling, "[T]he evidence .. . strongly support[s] the proposition that any increase (or decrease) in lending costs brought about by changes in the bankruptcy law will in the long run be passed along to borrowers or potential borrowers." 33 I assume this means that money will cost more or less in that credit market if there is an increase or decrease in borrowing costs, and that this is a simple, direct, functional relationship. Is the "long run" any time after present loan contracts have expired? Above all, how do we know when and if and by how much changes in the bankruptcy law will bring about changed lending costs?

\section{B. Some Evidence on Costs of Lending}

It may also be the case that not all consumer lenders act in a rational manner even in simple situations. I offer here as an example the matter of proofs of claim in bankruptcy. In the event of bankruptcy the bankrupt files schedules which identify each creditor and specify the amount of each debt. Every creditor then gets a notice by mail. He need only fill in a proof-of-claim form (a single legal-length page), attach a copy of the promissory note or receipt, and have the form notarized. This can be done by clerks of ordinary

30. See R. Eisner, Investment, 8 International Encyclopedia of the Social Sciences 185, 186 (1968).

31. Id.

32. One can assume that without maximizing profits the firms doing business would not have survived (see Friedman, supra note 15, at 22); but that may entail circular reasoning. Much of the consumer credit business has considerable legal impediments to entry by newcomers. That might change the process in the twenty-nine states that have convenience and advantage laws. See the discussion summarizing various views on the " $\mathrm{C}$ and $\mathrm{A}$ " clause in U.S. DeP'T of Commerce, Consumer Credit, Factors Influencing Its Availability and Cost ch. 4 (1976).

33. See note 2 supra and accompanying text. 
competence. The dividends paid to general (i.e., unsecured) creditors in all personal bankruptcies are nearly ten percent, and the mean claim in three New England states $^{34}$ three years ago was nearly $\$ 1,000$. Yet only 3 or 4 of about 17 or 18 scheduled and notified creditors filed proofs of claim in a sample of about 1050 bankruptcies. ${ }^{35}$ Surely that is not economically rational, not profit-maximizing behavior.

I doubt that most consumer borrowers know the costs of default, although they do have some implicit notion that default (including lateness) will result in more cost to them. But more to the point is that I question whether the lenders know the "costs" of alternative creditors' remedies. For example, if the common legally operative creditors' remedies could be valued paragraph by paragraph, with the consumer-borrower able to pay a sum to remove an offensive paragraph, I do not know how the lenders would calculate the value of some of the usual matters of contention. For this purpose I assume that the value of the remedy should be measured by the difference in cost and the availability of credit before and after addition or elimination of the remedy, assuming we can control for other differences. There are conflicting data on the question of increased risk to lenders. I offer the evidence of some recent natural experiments of legal history to support the view that not every difference makes a difference.

The legal doctrine called holder in due course (HIDC) provides a recent example. It has been argued back and forth by lawyers and economists what the impact might be of limiting or entirely prohibiting HIDC chattel paper. The HIDC doctrine can effectively insulate the financer (the assignee of chattel paper) from almost all legal defenses that the buyer-borrower has against the seller of goods. ${ }^{36}$ Obviously, there is an increase in legal risk and potential loss and simply a possible increase in transaction costs in financing without the HIDC insulation.

In May 1976 the Federal Trade Commission prohibited the use of HIDC instruments in consumer transactions with some minor exceptions. One would suppose that the increased risk would be revealed in the consumer credit money market and that, ceteris paribus, one could, by carefully monitoring the consumer credit money market, value the HIDC legal rights by measurement of credit availability and cost. The results of a tentative investigation by an

34. Connecticut, Massachusetts and Rhode Island.

35, Shuchman, Little Bankruptcies in New England, 56 Boston U. L. Rev. 685, 792 (Chart 5) (1976).

36. In the three-party transaction the retail installment buyer signs an instrument which is both a promissory note and a security agreement covering, say, a major appliance. The agreement is called chattel paper. The retailer sells (i.e., assigns) the chattel paper to a financer (at a discount) and gets cash. The retail buyer then pays the installments to the financer. If the financer is a holder in due course (HIDC), the retail buyer must continue to pay the debt even though the appliance is no good or the seller breached some warranty regarding the appliance. The retail buyer can sue the seller, but he must continue to pay the financer. 
outside group $\mathrm{p}^{37}$ are that loss of the HIDC rights has made almost no difference. Such differences as were found were still too small to affect the cost and availability of consumer credit. ${ }^{\mathbf{3 8}}$

There are other natural experiments based on differences in applicable state law. The states each have their own exemption laws. These laws provide that certain goods and money are exempt from legal execution process and hence, also exempt in bankruptcy. Exempt property is retained by the debtor, except for so-called purchase-money security interests. (These are secured loans the proceeds of which went to purchase the property). State laws vary considerably in the nature and value of exempt property. What is a considerable range depends perhaps on one's vantage point. Given the consumer debtor's situation, the difference between a state with no cash exemption, no automobile exemption, and no homestead (equity) exemption and states in which those items can be worth as much as $\$ 10,000$ or more is considerable.

How would one measure that range from the standpoint of the consumer lenders who do not have purchase-money security interests? Theory would have it that for lenders in states with large exemptions the risk is greater in the event of default (hence it is in absolute terms greater) and that the cost and availability of consumer credit would be affected as a function of that difference in risk. But the best empirical data we have suggest that the cost and the per capita amount of consumer credit does not vary along with differing state exemption laws. ${ }^{39}$

We do not know whether it is broadly true that restrictions on wage garnishment and wage assignment (what Dean Meckling terms "the individual's right to decide what claims he can offer on his labor income") "will significantly increase borrowing costs . . ."40 Some states do not permit wage gar-

37. Yankelovich, Skelly and White, Inc., A Qualitative Evaluation of the Impact of the Holder-in-Due-Course Rule on Lending Institutions (August 1976) (unpublished report of a study of 127 lending institutions in 4 states, conducted for the Federal Trade Commission). See also Waxman-Smith, Preserving Consumers' Claims and Defenses, 63 A.B.A. J. 1401 (1977).

38. There is some question whether the abolition of the HIDC rule in Puerto Rico had either a clear or dramatic effect, see Weistart, The Cost of Bankruptcy, Law \& Contemp. Prob., Autumn 1977, at 107. At least that should not be inferred from the cited source, Consumer CrediT IN Puerto Rico (1975). The archival data in that report only cover the years through 1973 and not thereafter, when the HIDC rule took effect. The conclusion is based solely on responses to inquiries made in 1975. It is not based on examination of business records, court papers, or other archives. The little information given on the impact of the HIDC rule is all qualified by the respondents having so "claimed." The respondents are, obviously, interested parties and the publisher of the report is the Puerto Rico Chamber of Commerce. When coupled with the absence of natural confirmatory data, these sources do not inspire confidence in the correspondence of the "claims" with empirical reality.

39. California; which, in my opinion, had the largest and most usable exemption laws of any state in the nation, ranks twentieth in the mean amount of per capita consumer credit from all sources. See 3 National Commission on Consumer Finance, supra note 29, Table 1000-1, at 14 .

40. Meckling, supra note 1 at 29. 
nishment at all. In Florida ${ }^{41}$ and Texas ${ }^{42}$ the lack of that effective creditors' remedy seems to have made no cognizable difference in the availability and $\operatorname{cost}^{43}$ of consumer credit.

Six states permitted debtors to waive by written contract their rights to claim exempt property. ${ }^{44}$ Where that waiver is lawful, virtually all consumer credit promissory notes contain such a provision. Consumer credit in those states, however, is neither cheaper nor more available. ${ }^{45}$

Thus the availability and cost of consumer credit may indicate that lenders cannot, or do not, place a financial value on these legal provisions. In other cases the legal or economic structure of particular markets prevents legal changes from having the expected impact on borrowing costs.

Meckling quite correctly observes that the intended consequences of statutory law are often frustrated. ${ }^{46}$ That is because there is friction in the legal system and also, I think, slippage-or at least discontinuities-in the financial markets of which we both speak. These gaps may be such that one can no longer look at the money market. Perhaps a better, more general model would include different money markets with different economic rules and different legal structures.

For many financial intermediaries, and especially for those lending to consumers directly or indirectly by financing the purchase of consumer durables, there is a statutory limit on interest and often a limitation in type of lending. ${ }^{47}$

41. Fla. Stat. Ann. $\$ 222.11$ (West 1961).

42. TEX. Const. art. $16, \S 28$.

43. In 1971 the national mean amount of consumer credit per capita was $\$ 495$. At that time two of the three states that prohibited wage garnishments were well above the mean. Florida, with a mean of roughly $\$ 600$, ranked seventh among the states, and Texas, with a mean of roughly $\$ 560$, ranked twelfth. Only Pennsylvania, at roughtly $\$ 487$, was below the national mean. See National Commission on Consumer Finance, supra note 29, Table 1000-1, at 14.

Texas was among the eight states with the highest rate ceilings for small consumer loans. See Durkin, A High Rate Market for Consumer Loans: The Small Loan Industry In Texas in 2 id. at 1.

44. See Annot., 94 A.L.R. 2 d 967 (1964), which lists those states.

45. While the national mean amount of per capita consumer credit from all sources was estimated to be $\$ 495$, in four of the six states which permitted the waiver of all debtors' exemptions in favor of creditors there appeared to be less per capita consumer credit. The states were Alabama, Louisiana, Maryland, and Pennsylvania. See note 43 supra.

46. Meckling, supra note 1 , at 17.

47. While other states had interest limits (i.e., usury laws of some kind), Connecticut had no limit for real-estate mortgages. Yet the cost of mortgages in Connecticut was within a relatively narrow range. For the largest mortgage banks in Connecticut, the range reached about $9 \%+$ or $-1 \%$. An increment of $1 \%$ is a difference in return of more than a tenth. But that is nothing like my example of an increase in return of half again as much, from $20 \%$ to $30 \%$. It was a fact of economic behavior of those firms that if the mortgage loan sought from one of those large financial intermediaries was not to be had within the "accepted" range (say $8 \%$ to $10 \%$ ) it was not to be had from the firm at all. Moreover, I think this is common practice in consumer credit of all kinds. This may represent an example of simple cost-plus pricing which may be better for the lender firms than a finer analysis that calculates relatively small differences in risk as differences in the price of the money sold. It may, of course, be an example of Dean Meckling's profit maximization model in that such rules of thumb are adequately efficient and less costly than 
Nearly all the states limit the amount and cost of small loans. Of the eight states with the highest regulated rate ceilings on small consumer loans, only three (South Carolina, North Carolina, and Alabama) were in the top fifth of the states in per capita credit of this type. In this particular, two of the eight states with the highest interest rate ceilings were well below the national mean. ${ }^{48}$ This particular market, or aspect of the market, seems not to respond to the rate of return as Meckling would suppose.

In the context of a model which aggregates all known borrowers and lenders the gross data tell us little about loan transactions that never took place. ${ }^{49}$ If the risk and rate of return are fully coupled, so to speak, the consumer money market will consist of different financial intermediaries at the supply end when both risk and rate of return are high. Different suppliers, new lenders, come in and go out of the consumer credit market within fairly well given ranges of return and type of transaction. At the point where the risk is so great that the interest rate is, for the same type of transaction, thirty percent instead of ten percent, the consumer is apt to be dealing with a different financial intermediary. ${ }^{50}$ Some consumers will not know of or be able to find other suppliers. Hence they will not, to any significant extent, deal with such financial intermediaries.

Meckling supposes "that eliminating misrepresentation as a defense"51 will result in "larger losses from bad debts" and "an increase in lending costs . . .." 52 This supposition may beg some questions by assuming certain empirical realities. ${ }^{53}$ We do have something of a surrogate for elimination of

other means of decision-making. See Baumol \& Quandt, Rules of Thumb and Optimally Imperfect Decisions, 54 Am. Econ. Rev. 23 (1964).

48. See National Commission on Consumer Finance, supra note 29, Table 1003-1.

49. Meckling's assertion about the loans that would and would not be made is largely a construct, an artifact of theory. It may be an analytic proposition based on the presumed empirical accuracy of predictions made from the usual assumptions of the shapes of the supply and demand curves in a single undifferentiated market.

50. I exclude small loan licensees which even under state regulations often are able to charge 30 to 40 percent or more. Their loan managers do not have the authority to adjust interest rates up or down except within a very small range. As a matter of fact the rates will vary little if at all.

51. See note 9 supra and accompanying text.

52. Meckling, supra note 1 , at 23 .

53. The term "fraud" is misleading and certainly not adequately descriptive. The setting must be explained: The typical transaction in which fraud is claimed is a loan from a consumer finance company. A standardized printed form headed "financial statement" or "loan application" is filled in by the borrower. He lists his assets and liabilities and then often handwrites the magic incantation "I have no other debts." Then the borrower, and in most cases the borrower's spouse, sign the form.

If the list of debts or liabilities is incomplete, then-in the event of bankruptcy-the lender claims to have relied on that misrepresentation and seeks to have the debt excepted from the effect of the bankruptcy discharge. Of course, lenders in fact rarely rely on the form. In the state of our first study of the fraud exception some three-fourths of all consumer loans from licensed lenders (the usual plaintiffs in these actions) were renewals of earlier loans. The lenders rely on that experience with the debtor and on credit reports. In short, the "misrepresentation" complained of by consumer credit firms is a fiction, in the form of legal archives. The financial- 
the fraud exception. Before 1971 the so-called fraud exception in section $17 \mathrm{a}(2)$ of the Bankruptcy $\mathrm{Act}^{54}$ was claimed in the state courts. Our best estimate was that in about eighteen to twenty percent of personal bankruptcies there was a lawsuit brought in the state courts to except a debt from discharge. ${ }^{55}$ Most of these were brought by licensed lenders, those in the business of direct loans to consumers. ${ }^{56}$ And most of those actions were successful. ${ }^{57}$ Then the law was changed so that the fraud exception had to be claimed in the bankruptcy court during the pendency of the bankruptcy or be waived. ${ }^{58}$ The frequency of such claims was roughly halved. ${ }^{59}$ Yet it did not appear that the per capita amount of consumer credit decreased. The cost did not change. It remained at the statutory maximum.

I have little information on how consumer lenders responded. But they could not impose "higher penalties for late payments." ${ }^{0}$ These are specified in the regulatory statutes. Nor could they always seek more security: in some states these firms cannot deal in secured loans at all.

There are some costs associated with claiming the fraud exception of $\S 17 \mathrm{a}(2)$, and those costs will be eliminated if the exception is abolished. I think it unlikely that the reduction in these costs by reason of less frequently asserting the fraud exception (because of the change in jurisdiction over such actions from the state courts to the bankruptcy courts) is equal to the amounts previously recovered. I expect it is the case for most licensed consumer lenders that loss of the recovery is greater than the reduction in the costs of litigation.

statement forms are designed merely to serve as evidence in the exercise of a certain legal right in the event of default and bankruptcy. The other purpose of these forms is for comparison with credit reports. In most of the consumer bankruptcies in which fraud is claimed, the guilty party is the lender. See generally Shuchman, The Fraud Exception in Consumer Bankruptcy, 23 STan. L. Rev. 735 (1971); Shuchman, Impact Analysis of the 1970 Bankruptcy Discharge Amendments, 51 N.C. L. REv. 233 (1972).

54. Act of July 1, 1898, ch. 541, \& 17a(2), 30 Stat. 550, as amended by Act of June 22, 1938, ch. 566, $\$ 17,52$ Stat. 851 and Act of July 12, 1960, Pub. L. No. 86-621, 74 Stat. 408.

55. Shuchman, The Fraud Exception in Consumer Bankruptcy, supra note 53, at 753-54 (1971).

56. Indeed one of the peculiar aspects of the fraud exception in actual practice is that the claimants (the creditor-plaintiffs) are mostly licensed lenders (and banks, installment sellers and their financers, and credit unions), that is, just those firms most experienced in the business. They are deceived by fraudulent misrepresentations resulting in loss so often that prudent highlevel managers, one supposes, would fire the negligent loan-office managers and hire new employees who would catch on and not be consistently deceived by those ill-educated but obviously very shrewd felonious borrowers. These lenders were "so easily bilked that their stockholders should be warned. During 1970, lenders claimed that as many as forty thousand or more bankrupt consumer borrowers had deceived them. Each deception occurred when a borrower induced a lender to make a loan based on a false financial statement." Shuchman, Impact Analysis of the 1970 Bankruptcy Discharge Amendments, supra note 53, at 236.

57. Shuchman, The Fraud Exception in Consumer Bankruptcy, supra note 53, at 760. Table 5 shows how these plaintiffs prevailed in $70 \%$ of our sample of cases.

58. Act of Oct. 19, 1970, Pub. L. No. 91-467, 84 Stat. 990.

59. Shuchman, Impact Analysis of the 1970 Bankruptcy Discharge Amendments, supra note 53, at 248-50.

60. Meckling, supra note $\mathbf{I}$, at 23 . 
One possible reason why such cost increases are not passed on to borrowers may be that the rates of return on equity in consumer lending firms are high enough. The supply capacity may be consistently less than the demand. It is a profitable business and the industry is growing. Of late, we have seen commercial banks entering the consumer credit market directly and indirectly by ventures into the credit-card business. Secured credit for automobile purchases has been extended to 42 months and sometimes to 48 months from the 36 month maximum term that had been customary for some time past. ${ }^{61}$

We do not know the "costs" of bankruptcy, although they are some function of the debts scheduled and discharged in bankruptcy and not recouped later. The difficulty in specifying this function can be seen in the fact that the rate of bad-debt writeoffs is not significantly greater in states with higher rates of bankruptcy. ${ }^{62}$ Thus there may be no extra cost to creditors attributable to bankruptcy over mere default. The legal imprimatur of a discharge in bankruptcy incurs a social cost. It is worth noting that, at the extremes, those states with the highest rates of bankruptcy have more than 23 times the number of personal bankruptcies per 100,000 population than the lowest states. But the bad-debt writeoffs at both extremes are within a multiple of four. ${ }^{63}$ Finally, the total amount of scheduled debt discharged in bankruptcy (not even considering what may be paid later) is minuscule in relation to the aggregate consumer debt outstanding and is not enough to affect the Nation's economy.

Meckling suggests that the costs which are passed back to borrowers could be reduced by more stringent creditors' remedies. ${ }^{64}$ But I doubt that the credit market would be much helped if we were to allow prospective borrowers to voluntarily agree to imprisonment. Since this would be a contractual arrangement, the state would have no interest in supporting the jailed delinquent debtor merely for a breach of contract. Dean Meckling would not want to curb the freedom to contract by making the breach a crime no matter what the parties agree (which only the Congress could accomplish); hence it is merely a civil wrong. Thus the creditor should pay for the incarceration of the defaulting debtor. Presently, the per-inmate cost of prisoner maintenance is about $\$ 26,000$ a year in New York. ${ }^{65}$ That makes Meckling's suggestion of jail for debt an unlikely prospect.

Really stringent creditors' remedies-for present example, debtors' jails -might very well result in reduced volume of lending. These would be less

61. See Wall St. J., June 6, 1977, at 32, col. 1 .

62. See Shuchman \& Jantscher, Correlation of Bad Debt Losses and Nonbusiness Bankruptcy Rates, 77 CoM. L. J. 358 (1972).

63. Id. at 359; National Consumer Finance Ass'n, Report on 1975 Nonbusiness BankRUPTCIES BY STATES, Table 3.

64. Meckling, supra note 1 , at 28.

65. Presumably, the cost would be less for noncriminals such as debtors. 
risky transactions, hence more profitable, assuming no other change. The money not used for consumer loans could be shifted elsewhere or, since financers borrow in the commercial money market, they would simply have to borrow less. But factors other than interest or return appear to be more important determinants. When we have less consumer credit, that appears to result more from macroeconomic influences such as widespread unemployment and contraction of the money supply due to governmental action.

Knowledgeable borrowers who balk at higher costs for credit have many means for avoiding them. They can avoid expensive types of loans such as revolving credit. Those in stronger positions can get single-repayment loans or can save and buy for cash. If they use secured credit, they can make larger downpayments so that the cost is less. For some consumers, it is relatively easy to discover that there are cheaper forms of credit.

It may well be that the persons who are hurt by the higher costs due to restrictions on wage garnishment and the use of bankruptcy by others are not the whole public but are members of the same group of high-risk borrowers. ${ }^{66}$ Thus the increased costs to which Meckling refers may not be diffused throughout the system to be borne by all the rest of us. Indeed the more astute and the more prudent the lender, the more that is apt to be true in a reasonably competitive setting.

To summarize: The problem of allocating the costs of default in consumer loans may not take place as a result of anything resembling the formal model described by Dean Meckling, although, as a theoretical statement, his model can be useful. If there is another bargaining party in that model of negotiation to an optimal resolution, it is the federal and state governments which interpose their powers between borrowers and lenders. The borrowers usually have little knowledge and little leverage. Efforts at making bargaining power less unequal, if not reaching parity, is what the consumer credit protection laws, including the reaffirmation and fraudulent-misrepresentation prohibitions, are all about. These legislative shifts are usually to bring about more "equity."

\section{The Borrower's Choice of Bankruptcy}

Having treated the first of Meckling's central propositions-the direct and invariable transfer of increased lending costs to borrowers-we can turn to the second-the free and rational nature of the debtor's choice of bankruptcy. Again, we find that the evidence seems not to bear out Meckling's theoretical assumptions.

The alternatives of straight personal bankruptcy, chapter XIII wage-

66. See Shuchman, supra note 24, at 427 . This is also suggested by Dean Meckling, supra note 1 , at 23-24. 
earner reorganization, ${ }^{67}$ and a miscellany of informal responses are open to the debtor and in some cases the decision "is a function of the costs and benefits to him. . . ."68 But it is an heroic assumption for Meckling to state them as though the debtor's election of an "arrangement" like chapter XIII of the Federal Bankruptcy Act is generally anything like a free choice, an informed, prudent decision.

I cannot expect economists to be aware of the apparent realities of how chapter XIII is chosen. There are some debtors who have too much to lose in straight bankruptcy and for them chapter XIII is in fact the prudent choice. If a debtor has enough nonexempt property and a steady, secure, and adequate wage, chapter XIII may be the most advantageous method of dealing with his creditors. ${ }^{69}$ Too, there are some debtors with moral compunctions about straight bankruptcy. They want to pay their debts. And not because it is more prudent or more rational, and not because they are profit maximizers. They think it is right to pay their debts and that they should (that normative posture) do so. Such a specific morality is a noneconomic cause of economic actions. It does not make its way into our economists' theoretical calculus.

But both these types seem to be the unusual cases. ${ }^{70}$ From what we can tell, most of the annual forty-thousand-odd chapter XIII's are, in one way or another, due to other, external pressures. Some of the evidence to support my view is anecdotal, but enough of the realities can be inferred from the consistent records of chapter XIII usage.

In a few federal districts there are very few straight personal bankruptcies; in these districts nearly all debtors "choose" to repay their debts (mostly by payment in full, the extension; infrequently by payment in part, the composition) by means of the chapter XIII wage-earner reorganization. There is no evident difference in the applicable state laws to account for or cause these

67. 11 U.S.C. $\$ \S 1001-1086$ (1970).

68. Meckling, supra note 1 , at 21 .

69. There may be other financial advantages. Interest at the contractual rate need not be paid to creditors after filing of the petition for reorganization, the chapter XIII plan. Hence the usual costs of administration, about $13 \%$ to $14 \%$, may be much less than the contractual rate of interest, especially for licensed lenders, sinall loan and finance companies. Even allowing for the $\$ 35$ filing fee, the differential could save the wage earner a substantial sum.

70. From the debtor's standpoint straight bankruptcy is preferable even if credit later costs him much more. The typical consumer-bankrupt is freed from debts of about $\$ 10,000$ to $\$ 14,000$. He is in his late thirties or middle forties. If he has another 20 to 25 years of employment and perhaps 20 years of possible borrowing, what would the additional cost of credit mean to him? If he has to borrow at $25 \%$ instead of the $12 \%$ rate for nonbankrupts, an additional cost of $13 \%$ is imposed upon him for all credit during that time. To offset those additional costs the bankrupt starts with a cushion of about $\$ 12,000$. This means that the bankrupt could borrow up to about $\$ 100,000$ over 20 years before the future costs of the bankruptcy would exceed the dollar benefits of the discharge. (This calculation does not include (1) the next 20 years' interest on the $\$ 12,000$ in discharged debt; (2) the costs and legal fees of bankruptcy, which, for an individual, range from about $\$ 300$ to $\$ 400$; and (3) the loss of nonexempt property in the bankruptcy.) 
vast differences. Sometimes there are dramatic differences in usage of chapter XIII's between the federal districts within one state. The applicable state law is the same. I have no reason to suppose that the debtors in one district or one state are more prudent or moral as regards debt payment than those in another nearby district or adjacent state. But, for example, the frequency of chapter XIII's in Kansas is about 28 percent of all personal employee bankruptcy filings while across the river in Missouri, such filings are only 10 percent chapter XIII's. And while all the districts in Alabama have about 77 percent chapter XIII's, the two districts in adjacent Mississippi have less than 2 percent chapter XIII's. ${ }^{71}$ I can find no differences in the state laws on exemptions that should cause much difference in bankruptcy filings, not to say such a dramatic difference.

New York State provides another example. It has four federal districts. In three of those districts the rate of chapter XIII's ranges from one percent to two percent of all personal employee filings. In the fourth district about 29 percent of all employee debtor filings are for chapter XIII wage-earner reorganizations. Here the applicable state law is the same. It is well to ask how this vast difference came to be, and why. Only some exotic economic theory can explain these phenomena on the basis that the "individual debtor's decision ... is a function of the costs and benefits to him of alternative courses of action."72

Chapter XIII Filings as Percentage of all Personal (Nonbusiness) Bankruptcies

\begin{tabular}{|c|c|c|c|c|c|c|}
\hline New York & 1970 & 1971 & 1972 & 1973 & 1974 & 1975 \\
\hline \multicolumn{7}{|l|}{ Northern District } \\
\hline Total Nonbusiness & 1,851 & 2,092 & 1,869 & 1,571 & 1,711 & 2,481 \\
\hline Chapter XIII & & 14 & 11 & 8 & 10 & 19 \\
\hline$\%$ & $0.2 \%$ & $0.7 \%$ & $0.6 \%$ & $0.5 \%$ & $0.6 \%$ & $0.8 \%$ \\
\hline \multicolumn{7}{|l|}{ Eastern District } \\
\hline Total Nonbusiness & 617 & 921 & 957 & 884 & 1,094 & 1,991 \\
\hline Chapter XIII & 3 & 11 & 11 & 5 & 9 & 26 \\
\hline$\%$ & $0.5 \%$ & $1.2 \%$ & $1.1 \%$ & $0.6 \%$ & $0.8 \%$ & $1.3 \%$ \\
\hline \multicolumn{7}{|l|}{ Southern District } \\
\hline Total Nonbusiners & 446 & 718 & 816 & 703 & 875 & 1,354 \\
\hline Chapter XIII & 3 & 6 & 4 & l & 12 & 26 \\
\hline$\%$ & $0.7 \%$ & $0.8 \%$ & $0.5 \%$ & $0.1 \%$ & $1.4 \%$ & $1.9 \%$ \\
\hline \multicolumn{7}{|l|}{ Western District } \\
\hline Total Nonbusiness & 1,999 & 2,423 & 2,393 & 2,304 & 2,639 & 4,199 \\
\hline Chapter XIII & 52 & 280 & 303 & 369 & 546 & 1,196 \\
\hline$\%$ & $2.6 \%$ & $11.6 \%$ & $12.7 \%$ & $16.0 \%$ & $20.7 \%$ & $28.5 \%$ \\
\hline
\end{tabular}

71. [1975] Director of the Administrative Office of The United States Courts Ann. REP. 461-463. These annual reports provide the information to generate the data cited in the following paragraph and table as well.

72. Meckling, supra note 1 , at 25. 
Dean Meckling's unproved assumption of the rationality of debtor's choices leads him to this conclusion about potential bankruptcy reforms: ${ }^{73}$

Changes in bankruptcy law which lower the costs or raise the benefits to debtors of one of these three options [straight bankruptcy, chapter XIII, or informal arrangements, including default] will without question increase both the number of debtors who elect that option and the total number of debtors who elect one of the three in preference to repayment.

Yet there is more evidence that does not support this conclusion.

Both costs and benefits to debtors have changed in manners that should serve as surrogates for actual change in the Federal Bankruptcy Act. These changes, in Dean Meckling's terms, "lower the costs or raise the benefits to debtors."

Because the Federal Bankruptcy Act invokes state law in the crucial matter of exemptions, the benefits to debtors in different states vary under the bankruptcy law. ${ }^{74}$ And states do from time to time change their exemption laws, thus in effect changing the bankruptcy law applicable to residents of those states. To the extent, then, that these changes in state law affect the relative cost of straight bankruptcy as compared to default and the chapter XIII wageearner reorganization, we can assay the impact of increasing benefits of one of these options.

States with larger exemptions do not necessarily have more bankruptcies, absolutely or as compared to chapter XIII's. There is, we found, a good correlation of bankruptcy filings with diminished severity of wage garnishment but not, so far as we know, with other exemptions of real and personal property, including cash. It is the case with wage garnishment that a limitation on that particular creditors' remedy will tend to reduce bankruptcy filings. ${ }^{75} \mathrm{I}$ do not know whether this is a reversible process.

When we examine sizable samples of bankruptcy petitions actually filed in adjacent states with considerable differences in the value of property that is exempt, we do not find that the bankrupts have changed their state of residence in order to take advantage of more liberal personal-property exemptions. ${ }^{76}$

By way of questioning the predictive powers of Dean Meckling's general and unqualified assertions about the effects of legal reform, I offer another example. For nearly two years one state (and federal district), Colorado, reduced the cost of access to bankruptcy for some persons by fifty dollars, less some slight margin. This direct example of lowering the costs of bankruptcy

73. Id. at 27 .

74. See 11 U.S.C. $\S 24$ (1970).

75. See Shuchman \& Jantscher, supra note 62 , at 360 .

76. The bankruptcy petition may be filed in the debtor's place of residence or domicile for the preceding six months. That time can be shortened. 11 U.S.C. \$ 2(a) 1: see Phillips' Nadler, The LAw of Debtor Relief $\$ 174-75$ (1972); Shuchman, supra note 35, at 693. 
arose from the litigated question whether indigents ${ }^{77}$ (defined by income guidelines set at about the accepted poverty level for a region) could file petitions in bankruptcy without payment of the statutory fifty-dollar filing fee.

Three stages of the positive law are relevant. The first is a ruling by the federal court of appeals in Boston. The case held that indigent bankrupts had no constitutional right violated by the statutory requirement that the fiftydollar filing fee be paid before a discharge could be granted. The Federal Supreme Court declined to review the First Circuit decision. ${ }^{78}$

But there are eleven federal circuits and, although courts-of-appeals decisions do bind lower courts in their circuit, district courts in other circuits are not so bound. This is true even where, as here, the Federal Supreme Court has denied certiorari, i.e., decided not to decide the case on appeal.

The second stage is a flatly contrary ruling by the federal district court in Colorado which held that indigents could file in forma pauperis but that the government would have a fifty-dollar judgment, unlikely ever to be enforced. ${ }^{79}$ Because of a mistake in procedure, and perhaps also for tactical reasons, the Colorado district-court decision was not appealed. The ruling was publicized throughout the state by the legal-aid group in Denver which had represented the bankrupt in her forma pauperis petition. Specimen forms were circulated to legal-aid offices throughout the state from the Denver office. ${ }^{80}$ Newspapers of general circulation also wrote about the ruling. ${ }^{81}$

Some 23 months after the Smith decision in Colorado the Federal Supreme Court resolved the issue, deciding that indigents did have to pay the fiftydollar filing fee, which could not be waived. ${ }^{82}$

Given that the Colorado district court was not bound by the Garland decision in the First Circuit, but was bound to follow the Supreme Court decision in Kras, I inquired what had happened between the Garland (Boston) and Smith (Colorado) decisions and between the Smith and Kras (Supreme Court) decisions. It was easily done because the Colorado district court did not follow the earlier decision of the Court of Appeals for the First Circuit in Garland. Also, the bankruptcy judge in Denver had the records of all forma pauperis petition filings. There were four more such bankruptcy petitions filed in the 23 months before the Supreme Court in Kras ended the practice. ${ }^{83}$

77. "Indigent" is defined by income guidelines set at about the accepted poverty-level for a region.

78. In re Garland, 428 F.2d 1185 (1st Cir. 1970), cert. denied 402 U.S. 966 (1971).

79. In re Smith, 323 F. Supp. 1082 (D. Col. 1971).

80. Practitioners were also informed. See The "Bankruptcy News Letter," Vol. 9, page 1 (Denver, Col.).

81. See, e.g., Denver Post, Feb. 25, 1971 .

82. United States v. Kras, 409 U.S. 434 (1973).

83. At that time (1970 and 1971) Colorado had about 3,000 straight nonbusiness bankruptcies a year. [1971] Director of the Administrative Office of the United States Courts Ann. REP. 388-391. 
I assume that the removal of a fifty-dollar cash outlay was a difference which lowered the cost of bankruptcy and made it more attractive, especially to those poor enough (by income) to meet the legal-aid eligibility guidelines. Obviously they had little assets; all had a negative net worth. Shouldn't this non-event be of concern to economic theorists? Surely theory would not have predicted the outcome, unless one answers merely by saying that the elasticity of demand for bankruptcy had some negative value. The bankruptcy process and the fluctuations in its use may have other, noneconomic causes, or may be stable in a manner that has little to do with economic causes. There may have been other influential factors. Maybe 23 months was not enough time for the anticipated changes to occur. In the event, these data are simple and easily checked. The Colorado situation seems to be a rebutting instance.

It does not appear to be the case, or at least the evidence we have does not bear out Meckling's contention, that changes in bankruptcy law that raise the benefits of bankruptcy to debtors or lower its cost will increase the number of debtors who elect the option of bankruptcy. ${ }^{84}$

Meckling also adds casual assumptions about the psychological costs of bankruptcy, for example, that bankrupts feel guilty about their failure to pay debts. ${ }^{85}$ There is little or no empirical evidence to support this assertion, although it appears that harassment by creditors sometimes does create psychic problems. The limited evidence we have from bankrupts (who are no longer harassed by their creditors) suggests that they perceive their bankruptcy as having been a good choice. Some four hundred respondents, interviewed two years after their discharges in bankruptcy, had generally favorable comments. ${ }^{86}$ Also, the psychological effects of bankruptcy (as compared to passive nonpayment) may vary greatly by type of person, social class, and peer-group support. $^{87}$ There may be psychological and perhaps even physical ${ }^{88}$ benefits

84. Professor Weston puts it that "if bankruptcy laws were eased, the quality of credit offered for sale would change, and the attractiveness of consumer credit would increase." Weston, supra note 16, at 52. This, too, is an empirical question not to be decided as a matter of fact by the structure of economic theory. (Or it may assume that the process described by Meckling is reversible, or both are using slightly different words in a natural language to state the same tautology.)

If this is a matter of economic definition, counterexamples will pose Professor Weston no problem. But in that case the proposition is empty of content.

If this is an empirical assertion, a prediction that as a matter of fact more consumer credit will be sought, then I reply that I know of no supportive evidence within the recent past range of actual bankruptcy law. The present politically possible changes (in particular, those discussed in Meckling's paper) in the bankruptcy law do not seem as great as some in the recent past and, I think, are unlikely to move events along the demand curve taken as a synthetic statement. In both events, some burden of proof should be assumed by Professor Weston, who should provide evidence in support of the assertion.

85. Meckling, supra note 1 , at 25-26.

86. See D. Stanley, M. Girth, V. Countryman, G. Jantscher, W. Law, V. Rosenblum, \& M. Shimm, Bankruptcy: Problem, Process, Reform 66 (1971). (57\% were strongly in favor.)

87. See Schuchman, supra note 24 , at $413 \mathrm{n} .19$ and the immediately preceding text.

88. This may be inferred from the findings of the Joint Economic Comm., 94TH Cong., 2D 
from debt liberation by discharge in bankruptcy. These may outweigh the guilt and the psychological costs which an individual might suffer because of his failure to fulfill a contract.

\section{Nonbusiness Bankruptcy: \\ Some Conclusions}

These examples suggest a few tentative conclusions, most of which are well known to economists, both theoretical and applied. There is sometimes little predictive value in the indifference curve that purports to show probable individual and industry behavior responsive to changes in legal risk. This is even more true of any subset of firms within an industry. Legal risk bears a sometimes unknown relation to return, because the legal risk is a determinant only in the event of default, and not always then. The examples also suggest that consumer creditors are not rational and prudent in the sense that economic theory would indicate, unless it is a theory with much more behavioral analysis and content than most economists will accept. I do not think it is enough to theorize that the lender firms and the individual borrowers do not in fact need to know and accurately calculate. These examples put into question the contentions that the behavior of consumer creditors and debtors can be explained by the hypothesis that they act "as if they were seeking rationally to maximize their expected returns . . . and had full knowledge of the data needed to succeed in this attempt." 89

Rate of return and legal risk are not functional equivalents although in some situations they may both be reduced to money. Legal risk, as we are speaking of it in this context, arises only in the event of default. In consumer credit this has ranged from one to three percent in the postwar period. Then, too, the loss is written off as a bad debt and up to half of the loss may be borne by the public fisc.

One can say that theory was not mistaken but the actual change in legal risk was less than had been thought. Although readers should be informed that financers have objected to most changes, including these examples, ${ }^{90}$ contending that the increase in risk would result in higher costs, preclusion of some groups from the consumer credit market, and so forth. The supply and demand curves given to us by economic theory are constructs. Our empirical information about consumer credit is not so accurate or complete as to predict except at the extremes. We are better at prediction in retrospect.

I would have supposed that economists might find good possibilities for

Sess., Estimating the Social. Costs of National Economic Policy: Implications for Mental and Physical Health, and Criminal Aggression (Comm. Print 1976) (H. Brenner).

89. Friedman, supra note 15 , at 21.

90. During a period for comments of less than two months the Federal Reserve Board received 1080 comments on the proposed HIDC rule of which only eight were favorable. Program, Holder in Due Course: Does the Consumer Pay?, 32 B us. LAw. 621 (1977). 
research in the few tentative examples I have raised and in other such instances. Instead, Von Mises describes the usual response: ${ }^{91}$ "[i]f a contradiction appears between a theory and experience, we [the economists] always have to assume that a condition presupposed by the theory was not present, or else that there is some error in our observation."

The proposed revisions of the Bankruptcy Act which Meckling has discussed would (i) eliminate the false financial statement as a basis for excepting a consumer debt from discharge, and (ii) make legally unenforceable contractual reaffirmations of discharged consumer debts. (There is nothing, however, to prevent a discharged bankrupt from later paying any or all of his scheduled and discharged debts in whole or in part.) There are not apt to be any significant effects resulting from those changes in the Bankruptcy Act. I conjecture that the impact of these revisions would be slight and, in the event, to those who cannot pay there will be too little transfer of wealth to make any perceptible differences.

As regards the politically possible revisions to the bankruptcy law designed to benefit bankrupts I conclude (1) they may increase lending costs slightly or may have no perceptible, adequately measurable, or significant effects on the costs of lending. We do not know of most such changes in creditor-debtor law whether they will in fact increase the number of bankruptcy filings or increase lenders' losses. (2) Such revisions as are comprehended may have the desirable effect of making consumer lenders more prudent and improving the overall quality and functioning of the consumer credit market. (3) If there are increased costs, who will bear them depends on how large the increase is and what alternatives are available to lenders and borrowers. If the increase is small and related business activities are not yet more attractive to lender firms, nothing may happen. Or the lender may bear the cost; or some of the borrowers-but by no means all-may bear the cost. Some of the "cost" may be in the form of denial of credit.

Meckling's theories may be correct in the commercial money market. But he may be mistaken in applying the model which fits that reality to all changes in risk in consumer credit. It is true in physics as well as in the social sciences that dimension and size can and often do make a great qualitative difference, one of kind, not merely degree. Classical mechanics accurately describes most observable phenomena. Contemporary physics does not so much show that classical mechanics is in error but, rather, specifies the contours of the areas where it will and will not apply and gives us the limits of what the theories can accurately describe. Similarly in the social sciences, what is true of small groups cannot be extrapolated to large groups. A jury of six is not merely half the size of a jury of twelve. These two groups function differ-

91. L. van Mises, Epistemological Problems of Economics 30 (1960). 
ently with what appear to be different results. The dynamics are not merely doubled or halved.

One can say of all apparently contrary-to-theory empirically based examples that the change in law was misperceived and did not in fact increase the risk. Instead, the losses remained more or less unchanged and the return was relatively stable. But that seems to me quite the vital aspect, for, except at the extremes, Dean Meckling's statement of theory does not permit us to predict what will be the impact of changes in creditor-debtor law, including bankruptcy laws. His examples assume increased bad-debt losses, which is the very question at issue in the two proposed changes in the Bankruptcy Act he discusses, the fraud exception and reaffirmations. Meckling says that "if changes in bankruptcy law increase bad debt losses, additional costs will be generated which will be borne by debtors and potential debtors." His analysis can be reduced: if bad debt losses increase and stay at the increased level, there will be additional costs. It may be misguided to search only for general rules to bring about just results or to make the legal system conform with what seem to be the exigencies or economic law of this little money market. I think it is much easier to work what Karl Popper termed piecemeal social technology. The starting point should be little injustices. Then the attempts to find out whether some particular legal or economic action produced the expected or desired results are more apt to be successful and the effects of failure are not so great. ${ }^{92}$

IV

\section{Corporate BankRuPtCY}

\section{A. Meckling's Concerns}

The second part of Meckling's paper deals with corporate bankruptcies, by which he means the very few large business bankruptcies. I understand his complaints with the present chapters X and XI to be threefold:

1. Stockholders are not "relegat[ed] to the status of pure residual claimants." 93 They can have no equity in a bankrupt corporation and should be entirely subordinated to the claims of creditors. Failing to do this results in higher costs of credit to the firm. So the shareholders get it put to them anyway, because their firm will have had to pay more for borrowed money. ${ }^{94}$

92. See Phillips, Forty Years On: Anti-Naturalism, and Problems of Sociäl Experiment and Piecemeal Social Reform, 19 Inquiry 403 (1976). See the discussion in Winch, Popper and Scientific Method in the Social Sciences, in 2 The Philosophy of Karl Popper 889, 890 (P. A. Schilpp ed. 1974).

Edmond Cahn's The Sense of Injustice provides more empirical guidance. The responses that arouse the sense of injustice are within a narrower range in which more agreement is more likely. Thus the pursuit of what is just is "the active process of remedying or preventing what [does or] would arouse the sense of injustice." E. CAHN, The Sense of Injustice 13-14 (1964 ed).

93. Meckling, supra note 1 , at 32 .

94. Id. at 33 . 
2. Meckling focuses on the difference between the "going-concern value of a firm and its liquidation value."95 This difference can be put in terms of money and can be paid over to the owners of the bankrupt firm (the same stockholders whose firm had to pay more for borrowed money because of this possibility as perceived by lenders). If, by means of chapter XI reorganizations, the "stockholders can capture [I see a Thurber wife in pursuit] more of the difference between the liquidation value of the firm and the going-concern value than they would by continuing operation, it will pay them to throw the firm into bankruptcy [i.e., reorganization under chapter XI] even though it is perfectly solvent."96

3. Courts are "systematically overestimating the value of the reorganized firm in order to give something to junior creditors and stockholders." 97 Meckling asserts that firms in reorganization under the Bankruptcy Act will be less arbitrarily valued by selling the firms at auction or by issuing claims on such firms and taking the total sale value of the claims as the value of the firm. ${ }^{98}$ These methods, he concludes, would result in market-determined values which, if combined with a rule giving absolute priority to creditors, would be the best overall method for effecting reorganizations.

Before questioning Meckling's axioms as applied to corporate bankruptcy, I offer as a transition a final tentative example of the presumed effect of bankruptcy law on the commercial money market. Simple economic theory is often implicitly accepted by legal scholars writing in the law journals. This may be illustrated in a commercial setting by the critiques of Constance v. Harvey, ${ }^{99}$ a case well known to law teachers in this field. The facts are that a creditor delayed in filing a chattel mortgage, which was finally recorded some ten months after the transaction. Under New York law any other person who extended credit after the last day on which the chattel mortgage should have been recorded until the date of the bankruptcy filing could defeat the rights of the chattel mortgagee, the secured creditor. In the event, no one else did extend credit during that ten-month period until the chattel mortgage was finally recorded. When the debtor-mortgagor became bankrupt, however, the Court of Appeals for the Second Circuit held that the trustee in bankruptcy had the rights of an "ideal" hypothetical lien creditor and could, therefore, invalidate the chattel mortgage even though there existed no actual creditor

95. Id. at 33-35.

96. Id. at 35. That extreme is not apt to be. Only an insolvent corporation can file in chapter XI. Still, there is some difference in value between the "same" firm on the auction block and operating under the advantages or handicaps of chapter XI.

97. Id. at 36 .

98. Id. at 38 .

99. 215 F.2d 571 (2d Cir. 1954), cert. denied, 348 U.S. 913 (1955). 
who could have done so. It was said that secured lenders were disturbed by the decision; that there would be an impairment of such credit, and that the cost of chattel mortgage funds would rise in the New York area.

The late J. A. MacLachlan strongly denounced the decision. He asserted that it "has, of course, made secured credit harder to get in the Second Circuit, and it has cast its shadow elsewhere." ${ }^{100}$ I assume the last phrase meant that secured credit was, though perhaps to a lesser extent, also costlier and more difficult to obtain in other states with similar recordation statutes. But Professor MacLachlan provided no evidence in support of his assertion. I think the reason may be that it seemed self-evident to him that since there was increased legal risk for secured creditors in the event of bankruptcy as a result of the Constance decision, secured credit would become more expensive and more difficult to get because secured lenders would seek other markets for their money. Of course, Professor MacLachlan's statement should not have been persuasive unless he had empirical evidence that secured credit was, in fact, "costlier and harder to get."

I have inquired with secured creditors and done a cursory investigation, and I have found no evidence that there was an increase in the cost of secured credit in New York shortly following the Constance decision in 1954. ${ }^{101}$ It may have been true that secured credit was costlier or in shorter supply as a result of the Constance decision. But no evidence is given by the legal scholars asserting that to be the case, although at the time they were writing, the natural experimental data of history would have been available to them.

I mention this example because of Meckling's insistence that there is a parallel between changes in personal and business bankruptcy law which increase risks, that wealth will be transferred from creditors to debtors or shareholders, and the consequence that credit will be more costly. Although Meckling states this conditionally, he seems to assume the reality: ${ }^{102}$

If efforts to treat stockholders more generously in bankruptcy ultimately impose costs on the bankruptcy process, those costs will in the main be borne by shareholders in the form of higher borrowing costs and reduced credit.

100. MacLachlan, Two Wrongs Make a Right, 37 Tex. L. Rev. 676, 679 (1959). See, e.g., 14 Vand. L. Rev. 1009, 1012 (1961); No. 1871, 86th Cong., 2d Sess. 10, 16, 31-32 (1960). H.R. ReP. No. 745, 86th Cong., Ist Sess. 9 (1959).

101. The limited information 1 could get from the reports that national banks filed with the Comptroller of the Currency, and from the Federal Reserve System, indicates that the amount of credit purchased did not change. Examination of the Wall Street Journal and the New York Times from before the unexpected decision of the referee in bankruptcy until after the Federal Supreme Court denied the petition for writ of certiorari revealed no sudden or sharp changes in the cost of money generally. Obviously, the composition of the total amount of credit could have changed.

Six years later in Lewis v. Mfrs. Nat'l Bank, 364 U.S. 603 (1961), the Federal Supreme Court explicitly overruled the holding in Constance v. Harvey. So far as 1 can determine, there was no abrupt change after the overruling Lewis decision in 1961.

102. Meckling, supra note 1 , at 33 . 
The problem is with that conditional "if." For we do not know too much about the actual impact on creditors' costs of most legislative changes that appear to increase legal risk in credit transactions, at least as regards those that are within the range generally attempted, excluding the usual extreme hypothetical changes.

Rate of return and perceived risk are determinative factors in commercial credit. More here than in consumer credit because there are so many submarkets and many more knowledgeable buyers of money. The difficulty with prediction based on these generalizations is, again, that legal risk is not the same as actual risk. ${ }^{103}$ Although these two bear some relation, we do not usually know what it is. And even when actual risk seems a reasonably direct consequence of legal risk, we do not know what the results are in terms of cost. ${ }^{104}$ The potential risk in the bankruptcy law may only be realized in the relatively few loans that result in both default and bankruptcy; and the actual costs of the realized risk are difficult to determine and probably not often calculated by lenders.

The landmark cases we write about are atypical. Mostly, they represent the one-time marginal cases. Communication of such decisions is rapid and widespread. One appellate decision can change the forms and practices over several states or even nationally in the law of bankruptcy. Legislation can be anticipated and, to a lesser extent, allowances can be made for possibly adverse adjudications of an authoritative appellate court. I doubt that most of the federal courts-of-appeals and Supreme Court decisions in businessbankruptcy law have had more than a slight, if cognizable, impact on losses and on the cost of money in the commercial money market. The decisions do result in work for lawyers who must see to changes in forms and practice. And they are very good material for law teachers who are gainfully employed in analyzing such cases.

\section{B. Business Failures}

Meckling suggests that most of the bankruptcies which are classified as business bankruptcies have more in common with personal bankruptcy than with corporate bankruptcy. ${ }^{105}$ The distinction is not new. ${ }^{106}$ The difference to the individuals in a business bankruptcy is, however, often of great consequence. The legal form of the business, whether a corporation or other form of legal entity, is not the distinguishing factor. In many states small individual or partnership businesses such as taprooms and taxicab franchises are incor-

103. See page 89 supra.

104. See note 62 supra and accompanying text.

105. Meckling, supra note 1 , at 14 .

106. See, e.g., House Comm. on the Judiciary, Bankruptcy Law Revision, H.R. Rep. No. 595, 95th Cong., Ist Sess. 6 (1977) [hereinafter cited as Committee RePorT]. 
porated to obtain financing and to facilitate transfer. I think it is also true that many small-business failures do not end up in the bankruptcy court, but that the owner-managers file petitions in bankruptcy because of personal liability incurred in raising capital. ${ }^{107}$ The personal discharge may be the most important factor in small-business bankruptcies. The distinction between personal and business bankruptcy may, in more frequent reality, be that of small and large enterprises upon which are superimposed the same legal conditions for credit transactions of different types, involving different parties.

This analysis is supported by a finding that nearly four-fifths of loans to small business were secured, compared to less than one-fifth of the loans to large business which were secured. The type of security which the small business typically provided as collateral was also different; it was of a more personal nature, such as life insurance and savings accounts. ${ }^{108}$ Then too, the small-business owners have to personally endorse the business loans, much more often than large business firms, by means of a residential mortgage or the spouse's signature as comaker.

Although the size of the firm is probably the most important distinction between most business bankruptcies that are small and better termed personal and those few so large as more accurately to be described as corporate bankruptcies, one can also categorize business bankruptcies by whether they result, so to speak, from causes generated by the situation of the individual firm. Most business failures are very small firms that sell services or are service based. Such enterprises as beauty shops, restaurants, clothing producers and sellers, are more apt to become bankrupts, even if that is preceded by a chapter XI proceeding. ${ }^{109}$

The institution of bankruptcy also has to be related to the broader economic framework. The kinds of massive influences that result from failures in governmentally imposed macroeconomic policy cause bankruptcies that are not inherently associated with the activities or failings of a firm. There are probably many bankruptcies and chapter proceedings that are due to macroeconomic causes over which even prudent managers had no control, nor could they prevent the disastrous impacts upon their firms. If a firm is forced out of business because money suddenly becomes very expensive or unemployment rises sharply, it seems inappropriate to use the terms "failure" or "fault" or to have a bankruptcy law that implicitly accepts that notion by unnecessarily penalizing the stockholders and managers. This seems especially

107. Twin chapter XI reorganizations-one for the firm and another for the ownermanagers-are, I think, common, although I know of no data on this matter. Corroborative comments from a practitioner are in Leibowitz, Officers' Personal Liability for Corporate Debts When Bankruptcy Ensues, 82 Сом. L.J. 10, 12 (1977).

108. See Security Pledged on Business Loans at Member Banks, 45 Fed. Res. Bul... 1114, $1116-18$, 1127 (1959).

109. See 11 U.S.C. $\$ \S 701-99$ (1970). 
true with the very small firm typical of those that end up in bankruptcy, or first in reorganization and then in straight bankruptcy. These bankruptcies may be due to external or governmental causes. Such problems may be at least as much social as economic.

If this suggested division is accurate, it may be worthwhile trying to distinguish those business failures that are appropriately dealt with by the Bankruptcy Act from those for which we might want a governmental policy to ameliorate or undo the bad results of other governmental policies. ${ }^{110}$ For the latter category it is worth considering the creation of an agency (whether public or private) that would help potentially profitable firms to merge or to be actively helped through a chapter reorganization.

\section{Corporate Bankruptcies}

There are other differences between straight bankruptcy and corporate reorganizations, the chapter proceedings. Most business firms that fail simply close their doors and are no more. In some few a bankruptcy petition-usually voluntary-is filed. In these straight business bankruptcies the problems are those of efficiency in an orderly proceeding of distribution. There are serious questions whether liquidations in straight bankruptcy under the control of the bankruptcy court are as efficient as they might be. There are questions of the relative priority of creditors' claims which, again, lawyers tend to view more as problems in equity, although there is some allocative impact. About a tenth of the business bankruptcies are reorganizations. Nearly all of them are under chapter XI, which, it is generally thought, offers the advantages of being more flexible, less expensive, and speedier. The reorganizations take the forms of compositions, extensions, or both. Most business reorganizations are compositions (i.e., payment of much less than the full indebtedness) as well as extensions. That is not, however, true of wage-earner reorganizations under chapter XIII, most of which are only extensions.

\section{The Valuation of Firms in Bankruptcy}

Putting aside such questions and taking the present legal system as given, ${ }^{11}$ why should bankruptcy law accept the market value (as determined

110. This was one of the arguments made to the Congress in the Lockheed loan guarantee hearings. See Hearings on H.R. 8432 before the House Comm. on Banking and Currency, 92d Cong., l st Sess. (1971). These considerations may also apply to wage earners who, by reason of such causes beyond their control, are unemployed.

111. Meckling seems to think it would be disastrous "if the law were altered to provide that stockholders have first claim on the value of the firm in case of bankruptcy. . ." Meckling, supra note 1 , at 30 . I doubt that the Republic would fall. I assume that creditors would rely less on the anticipated earnings of debtor firms and would, instead, get perfected security interests in collateral that could be liquidated. That is the general situation at present for most small business firms and their creditors. I doubt that such a change in the legal model would make much difference for the large business firms Meckling lists (assuming no legal constraints on the lending activities of such creditors). 
by auction sale or sale of claims) at the time of the proposed reorganization as best? The major reason we do not is that the courts have rejected strict notions of market value because in the past (before chapters $X$ and $X I$ ) the junior creditors and small investors (numerous and unorganized) have been, it was thought, treated inequitably by those creditors in a position to take advantage of liquidation with the functional equivalent to absolute priority for themselves. Whether or not this was true in enough cases is an historical and empirical question; also it requires some more or less agreed notions of what is equitable treatment and for whom and under what circumstances.

The object in practice of the absolute priority rule seems to be the distribution of new claims to the reorganized firm which fulfill the general aim of being equal to the creditors' present claims for which they were substituted. This should take place within some reasonable time. Obviously the absolute priority rule assumes there will be an increase in the value of the firm over its liquidation value due to the advantages of the approved plan of reorganization. That is the very purpose of reorganization. If the immediate future re sembles the present, i.e., other things being equal, the reorganization will enable the business firm to increase in value.

There is a difference between the market value as Meckling defines it (at immediate auction sale or by auction sale of claims) and the reorganization value of a business firm. The latter may be viewed as but another and perhaps better measure of value: the market value over time of a presently failing business with, however, the additional and usually valuable factor of a court ordered reorganization.

From Meckling's assumptions it does not necessarily follow that the actions of the reorganizing debtor will be detrimental to creditors. Just as it may be that the courts and the S.E.C. can find the "true" value of a going business (if, indeed, there is such a number) it may also be that Meckling's "market" value is only the auction value at that time and place with the business firm in that condition. Such a valuation may be equally arbitrary because the immediate market in a more or less forced sale may not be a good or the best guide for the valuation of a firm being reorganized. ${ }^{112}$

\section{The Absolute Priority Rule}

Mr. Meckling's concern about the value and valuation of firms in bankruptcy is related to his belief that the division of that value between creditors and stockholders is mistaken and will lead to bad consequences. He feels, quite strongly, that if the firm's value is less than the total claims of creditors, then there should be nothing paid to the stockholders-indeed nothing left for them-until after the creditors are immediately paid upon sale of the

112. See Bell, Valuation and the Probability of Bankruptcy in Chapter X, 52 Am. Bank. L.J. 1 (1978), which analyzes several different means of valuation. 
firm. ${ }^{113}$ This reasoning is in part based on the absolute priority rule which, in general terms, proscribes any arrangement in reorganization which subordinates the rights of creditors to those of stockholders. ${ }^{114}$

One problem is that what kinds of debts and which creditors are senior depends on the antecedent legal system. ${ }^{115}$ For example, should banks have the nearly absolute right of set-off ${ }^{116}$ To the extent they do, banks will be senior creditors unless another creditor pays for some contractual arrangement to the contrary and "monitors" the debtor to insure that no other bank accounts are opened. Should transactions within four months of bankruptcy be subject to the sometimes complicated rules regarding voidable preferences? How much legal power should the trustee be given to recover for the benefit of creditors what might be assets of the bankrupt firm in the possession of another? How compensate the trustee for his efforts? Will we take the trustee's fees and costs out of the whole bankrupt estate or only from the unencumbered assets (i.e., those not subject to a security interest or other lien)? In the latter case only general creditors bear that burden; in the former, all creditors fund the trustee's work.

One very pressing question is whether we should rank the rights of creditors as we do now between secured creditors and general creditors. Should those secured creditors who are first in time be first in right as regards priority in distribution of liquidated assets? Typically, these days, the first large creditor has a "floating lien," a security interest in collateral such as accounts receivable and inventory that is not yet in existence. These legal rights which presumably have financial consequences have changed considerably from time to time in recent history. At present, the secured creditors have the stronger hand. But that is not by reason of any inexorable laws of finance theory but because the drafters of article 9 of the Uniform Commercial Code were biased in that direction.

113. "It is difficult to reconcile the proposition that a firm is bankrupt with the proposition that stockholders have some positive equity." Meckling, supra note 1, at 32.

114. [T] he absolute priority rule requires a recognition of nonbankruptcy priorities in corporate reorganization under the Bankruptcy Act. It represents the general principle that creditors, in the order of their nonbankruptcy priorities, are to be satisfied in full from the debtor's assets before the debtor may retain any interest in those assets.

Trost, Corporate Bankruptcy Reorganizations: For the Benefit of Creditors or Stockholders?, 21 U.C.L.A. L. REv. 540, 541 (1973).

Under Chapter $\mathrm{X}$, the financial standard for confirmation [of a plan] is the absolute priority rule. Under that rule, creditors are entitled to be paid according to the going concern value of the business, which is usually higher than the liquidation value of the business because assets in operation can usually earn more than assets sold for scrap.

BANKRUPTCY REPORT, supra note 9, at 223.

115. Most of the litigation in business-bankruptcy cases (including reorganizations) is not between the insolvent debtor and its creditors, but between creditors competing over the assets of their common debtor.

116. For a recent example of this problem, see Katz v. First Nat'l Bank of Glen Head, 568 F.2d 964 (2d Cir. 1977), cert. denied, U.S. , 98 S. Ct. 1250 (1978). 
Indeed these considerations apply as well to one of Meckling's bedrock assertions. Whether stockholders should be "relegated to the status of pure residual claimants" as he contends, is also a function of the antecedent legal system. I doubt that this doctrine can be shown to be the result of any necessary principles of finance theory or to be essential for economic efficiency. It appears to be a normative statement, even an exhortation. On Meckling's reasoning it seems likely that if stockholders get greater rights, that is where more money will go, on better terms, at lower cost.

Even given Meckling's theories, it may be desirable to encourage equity investments such as the purchase of stock in what are thought to be risky undertakings. If stockholders are given greater rights in the event of chapter XI reorganization they might be willing to pay more for borrowed money, which is what Meckling claims will inevitably be the case. A bankruptcy system such as Meckling suggests-one with greater creditor control and where all creditors have more rights-might inhibit the creation of new, innovative, and high-risk enterprises. To the extent that the allocation of resources into hazardous areas contributes to economic growth, we might all lose as a result.

\section{Some Evidence on Chapter Reorganizations}

Mr. Meckling, as we have seen, goes immediately to market: sell the bankrupt firm at auction or sell claims to the reorganized firm, both sales subject to the absolute priority rule that creditors are to be paid in full before the stockholders get anything. They are to be strictly "residual claimants." Given this position it is evident that he would conclude that shareholders now receive too favorable a treatment in corporate reorganizations. ${ }^{117}$

Most chapter proceedings "fail" in the sense of not continuing in business although often they do pay what the approved plan proposed. Given the alternatives of liquidation under straight bankruptcy in which the dividends paid are almost certain to be substantially less than what a chapter plan can offer and in fact pay, the general creditors (and often even the secured creditors) are apt to favor chapter reorganization. There are, however, enough successful reorganizations (extensions, compositions and both) under chapter $\mathrm{XI}$ so that the rather formalistic model stated by Meckling is at least questionable as a matter of empirical fact. ${ }^{118}$

The idea that a firm can somehow be solvent in the long run but temporarily unable to meet its obligations will not withstand careful scrutiny. If the firm has a present value which exceeds the sum of the claims held by creditors, it should always be able to meet its current cash-flow requirements simply by substituting new loans for old.

117. Meckling, supra note 1 , at 33 .

118. Id. at $32-33$. 
I do not have data from enough recent chapter XI proceedings to know whether or not it is true that stockholders often or consistently get more favorable treatment than creditors in such corporate reorganizations. I do not know how frequent are the "occasions on which it pays creditors to concede something to shareholders in order to keep the current management." 119 Neither, I think, does anyone else. It would seem most apt to take place in smaller firms in which particular skills and knowledge cannot be as easily replaced as in larger firms with more managers.

He goes further. "[S]tockholders (through management)," Meckling claims, will "petition for bankruptcy ... whenever the present value of the cash flows which their claims would yield if the firm continued in operation falls below the present value of the claims they would receive in a reorganization." 120 This assertion seems based on a theory of behavior converted into an inexorable law of Meckling's economics. There may be a correlation between the state of affairs he posits and the event of voluntary bankruptcy, but, as is his wont, Meckling offers no empirical evidence. Even so, a mere correlation would not satisfy Meckling, if I read him correctly. For he is asserting a direct causal relationship, and an invariable one at that. I think his conjecture is wrong and would not be supported by scientifically gathered data.

Most of the evidence on the large chapter proceedings is (1) from railroads being reorganized under chapter 77 , regarding which inferences to other firms in unregulated industries may not be warranted; (2) from anecdotal evidence not scientifically gathered or analyzed; or (3) from the few large chapter proceedings. ${ }^{121}$ There are "horribles" in any group of lawsuits, and there are also the exemplars of what chapter XI proceedings should accomplish. But we do not have any body of knowledge adequate in size and properly gathered to inform us what the results are in the mass so that this legal process can be evaluated.

Mr. Meckling provides quotations but little empirical information to support his contention that the owners of debtor firms compel the creditors to accept unfavorable chapter XI plans. For example, the National Bankruptcy Conference statement that "a review of the present use of chapter XI may demonstrate that . . creditors . . . are in a most disadvantageous position" 122 is based on apprehensions and perhaps some particular cases and anecdotal

119. Id. at 36 .

120. Id. at 35 .

121. By SEC standards there are some 13 million small business firms in the Nation. They account for $55 \%$ of all private employment, $48 \%$ of all business output, and $43 \%$ of the gross national product. See N.Y. Times, July 4, 1978, § D, at 25 . Anecdotal evidence from a few large corporate reorganizations may be irrelevant to nine tenths of all business firms. See E. Mason, Corporation, 3 International Encyclopedia of the Social Sciences 396 (1968).

122. Bankruptcy Act Revision: Hearings on H.R. 31 and H.R. 32 Before the Subcomm. on Civil and Constitutional Rights of the House Comm. on the Judiciary, 94th Cong., 1st \& 2d Sess. 1874-5, quoted in Meckling, supra note 1 , at 33-34. 
evidence, but not on any systematic investigation. There has been no "review of the present use of chapter XI." The same objection applies to Mr. Trost's article cited by Meckling. ${ }^{123}$ Indeed the Report of the House Judiciary Committee concedes that there are little data on the make-up of chapter XI proceedings. ${ }^{124}$

Altman's data are better gathered and analyzed. Meckling's reference to Altman's findings are questionable. ${ }^{125}$ Altman's study involved only large corporate bankruptcies: all but two of Altman's cases were chapter X's and railroad reorganizations. ${ }^{126}$ These are not, even if the data were as Meckling asserts, good evidence for the failings of chapter XI reorganizations due, he claims, to deficiencies in the law of bankruptcy reorganization.

Meckling makes much of the Muntz TV bankruptcy. But Altman explains that the result in the Muntz TV bankruptcy is anomalous, and adds only one other example, also apparently unusual. ${ }^{127}$

Altman concludes that "[ $t]$ he common stockholder experience in bankrupt firms is, on the average, not nearly as good as it was with Muntz TV, but in a surprising number of bankruptcy reorganizations, the old shareholders have done significantly better than most analysts and theoreticians would have expected." 28 But not better, I think, than businessmen, experienced lenders, and lawyers would expect in a reasonable run of cases. There is such great variation that inflexible rules rigidly applied are apt to work no better in bankruptcy than in most areas of law.

The common experience of stockholders in bankruptcy reorganization does not appear to be nearly so favorable as Meckling claims. Since he makes that statement just after mentioning the Muntz TV bankruptcy, one supposes that these are the data that show how frequent it is that "stockholders actually fared better" in the reorganization "than unsecured creditors."129

The import of Altman's commentary is that the longer the reorganization the better the chances that stockholders will recover more of their original investment (taken as the value of their equity just before the bankruptcy). There is no comparison here between creditors and stockholders. Altman's

123. Trost, supra note 114 , quoted in Meckling, supra note 1, at 34. Mr. Trost restates a general principle true in much of creditor-debtor law-but by no means in all creditor-debtor law-that a business firm holds its assets as "a trust fund charged primarily with payment of corporate liabilities." Id. at 541. That principle is based on opinions written in various appellate court decisions; it is thus subject to revision or complete reversal by subsequent decisions. A legal system without that principle is not inconceivable.

124. See Committe Report, supra note 106, at 252.

125. E. Altman, Corporate Bankruptcy in America (1971), cited in Meckling, supra note 1, at $\mathrm{n} .53, \mathrm{n} .54$.

126. Id. at 129 , n.8.

127. Green River Steel Corporation. Id. at 113-20.

128. Id. at 104.

129. Meckling, supra note 1 , at 32 . 
data, in their context, ${ }^{130}$ show that in thirty-four of fifty-two reorganized firms (about 65 percent) the stockholders suffered a total loss within two years and that five years into bankruptcy reorganization the stockholders did better. Over the five-year span, in forty of ninety cases (some 44 percent) the old stockholders "participated." That is, given more time for reorganization, the stockholders did better as measured by the fraction of their "original investment" recovered.

Even if Professor Altman had found many instances in which old stockholders shared in the settlement, that is not equivalent to the proposition that general creditors were, therefore, badly treated or dealt with in some manner that is economically inefficient. Indeed, apart from Meckling's warnings about the increased cost of borrowed money (an assertion without empirical verification in the context of reorganization under chapter XI) I doubt that it would make much difference. Meckling, instead, seems to say that if the stockholders get any claim at all in a reorganized firm, that consequence cannot be reconciled with the proposition that a firm is bankrupt. These may be problems in logic as applied to propositions stated in natural languages.

However, from virtually no evidence (except two of Altman's chapter X's which are constrained by the absolute priority principle) Meckling concludes that "stockholders frequently get valuable claims in corporate reorganizations." "131 Part of this conclusion is based on another formal principle which must involve some unstated definitions and connections (at least it is unclear whether his definitions are descriptively based or are simply stipulative): "The idea that a firm can somehow be solvent in the long run, but temporarily unable to meet its obligations will not withstand careful scrutiny."132

It is an unusual scrutiny which Dean Meckling brings to bear in rebutting this proposition which is not the bankruptcy scheme. It is not necessarily true of reorganizations that the decree of a court or even the agreement of the parties means that a firm is or is said to be "solvent in the long run."

By way of rebuttal Meckling asserts another formal principle (it may have empirical confirmation but none is provided): "If the firm has a present value which exceeds the sum of the claims held by creditors, it should always be able to meet its current cash-flow requirements, simply by substituting new loans for old." 133

Is it a logically impossible proposition that there exist firms whose present value is greater than the claims of creditors but who cannot pay their matured debts? It can be a tautology if value is defined as that sum which a business firm can always borrow. But this is not the usual definition of value and it does not appear to be the definition Meckling adopts elsewhere in his paper.

130. E. Altman, supra note 125 , at 132-33.

131. Meckling, supra note 1 , at 33 .

132. See note 118 supra and accompanying text.

133. Id. 
Can it be that whenever any firm cannot meet its "current cash-flow requirements by substituting new loans for old" the value of that firm is necessarily less than what it owes? That could be another definition of present value.

His definitions and formal principles tell us how Meckling thinks, in what structure and with what grammar and syntax. Meckling's strictures-whether they are viewed as axioms or as derived from his world view-do not inform us about other empirical realities. It may be true that stockholders frequently get valuable claims in corporate reorganizations. But neither Meckling nor any of those he cites have provided evidence to determine whether or not the statement is true in any significant degree.

I do not know and it is not captious to ask whether the effects of Meckling's rhetorical questions as supposition (stockholders having priority over creditors in bankruptcy) would be as he hypothesizes. Nor do I know what significant differences, if any, would result from not-limited or partly limited liability of stockholders in the event of corporate bankruptcy. For many small firms, substantial portions of the firm capital are raised by the security of the individual entrepreneurs, the owners pledging their personal collateral (and also, individually ending up in chapter XI's). For the larger firms, the risk of not completely limited liability for stockholders is far less and, given that legal status, the stockholders might organize to do a better job of policing and monitoring. The changed legal situation might result in the creation of new agencies to perform those functions and better protect the stockholders.

In the reorganization context (as in the consumer bankruptcies) it is incomplete and misleading to lump all classes of creditors. The creditors must accept the proposed plan of reorganization. If the creditors act through a committee they may have enough common interests to alter a plan or insist upon and get the modifications they want. (There must be approval by a majority of the creditors in number and amount for each class of creditors in the reorganization plan.) Priority creditors are generally protected by the requirement that the debtor corporation (or individual) deposit enough funds or the equivalent to pay their claims. The largest and most common of the priority claimants are various taxing authorities, especially the federal government. Often the difference between an accepted and successful plan and one that never flies at all is the attitude of the tax claimants.

Secured creditors do not lose their liens in whatever collateral is their security. Although the security interest is sometimes "affected" (a word of art in the bankruptcy law) they do not lose their security nor does the value of their collateral diminish by more than what they are paid under the reorganization plan over the same time. ${ }^{134}$

If, in straight bankruptcy, secured creditors (probably a tenth or less of all

134. Although there are occasional exceptions such as In re Yale Express System, Inc., 384 F.2d 990 (2d Cir. 1967) (chapter X). 
business creditors by number) do not get out of the bankruptcy more or less whole, it is because the security they held was worth less than the amount of their debt. I think the common result that secured creditors in business bankruptcies do not get more than forty percent or so of their claims is because secured lenders rely on the anticipated earnings of the debtor firm; more so than in personal bankruptcies, where secured creditors consistently recover some two-thirds of their claims either in the bankruptcy distribution or upon their own liquidation of the collateral.

It is a common complaint of trustees and other creditors that because the policy of the Uniform Commercial Code so strongly favors secured creditors, there is little of unsecured assets left; not enough, they claim, to pay for proper administration and not enough to make it worthwhile for the other creditors to participate actively. The secured creditors have more legal leverage than the stockholders in straight bankruptcy and in most reorganization proceedings. If the secured creditors do not assert their legal rights, for whatever reason, that does not prove that the stockholders have too much power in chapter XI proceedings or that the stockholders abuse that power. ${ }^{135}$ It may also be that trade creditors want to keep a business going even at the expense of losing some or all of that difference between the values of the business on liquidation and as a going enterprise. Trade creditors have been known to cooperate in common law compositions and extensions to that end.

But most of this is conjecture responsive to Mr. Meckling's conjectures. Neither of us knows. I do not think any of us knows enough of the consistent and widespread realities of chapter XI to recommend substantial change in the legal model. As we have no data on the present situation in any adequate sample of chapter XI reorganizations, how could we know what was the effect of Mr. Meckling's proposed changes even were they implemented?

\section{Conclusions on Business Bankruptcies}

The accepted purpose of corporate bankruptcy is to bring about the orderly and efficient liquidation of the failed business. One important test of a good bankruptcy system is how efficiently the process moves asset resources into more productive and profitable uses. If, in addition, it can be shown to

135. Dean Meckling's earlier example (taken from Bankruptcy Act Revision: Hearings on H.R. 31 and H.R. 32, 95th Cong., 1st \& 2d Sess. 1910 (1976)) may not represent what he supposed. It may be a case of some few creditors trying to get a little extra, some vigorish, so to speak. Only three creditors out of several hundred, representing about four percent of the debt, waited two years after the proceedings had been started. The chapter XI plan had been formulated and was accepted by all but those few recalcitrant creditors who insisted that their debts be nondischargeable. The example may show that creditors do have great powers in reorganizations and it may also show how important are controlled, orderly, and equitable proceedings.

Most practitioners think that the largest impact of the absolute priority rule in chapter $\mathrm{X}$ is that it is used as a threat by creditors or creditors' committees "to extract concessions from a debtor in the formulation of the [Chapter XI] plan." CommitTEe RePORT, supra note 106, at 223. 
be likely that Meckling's suggested approach will yield more for creditors, especially general creditors, in more cases, then it should at least be a required alternative to be examined. ${ }^{136}$ It might be better (more orderly and more efficient) to have the firms in chapter proceedings and straight bankruptcy immediately put up for sale as going enterprises. We might use the bankruptcy court or some equivalent agency as an intermediary to help arrange mergers. Some trade associations perform such functions. If the antitrust laws might apply and inhibit or actually restrict mergers that might avoid the losses due to liquidation, the Congress or the Supreme Court by its rulemaking powers could empower the district judges to involve the Department of Justice and the Federal Trade Commission. A broader series of exceptions to the general laws of unfair trade practices and lessening of competition, or merely investing discretionary power in the district court judges might accomplish the goal of less liquidations and more mergers.

The legal classifications, the typology of senior and junior creditors, arise out of nothing necessarily in the nature of things economic. These categories result from political bargaining and lobbying as much as, or more than, from judicial decisions. There have been other systems for deciding which creditors or classes of creditors come first and to what extent throughout legal history. In American legal history these considerable differences have not caused the economy of the Republic to collapse. Indeed, at present and for some time past, one part of the "antecedent legal system," maritime lien law, appears to function reasonably well with a rule that roughly gives priority to the last lienor-creditor. ${ }^{137} \mathrm{He}$ is the one who, it is presumed, enabled the ship to sail.

What Meckling takes as the subject matter of scientific analysis of financial market forces may be the study of different markets, not to be described by a single model. Also, the consumer credit market and to a lesser extent the commercial credit market are determined by the relative allocations of various kinds of coercive rights created and enforced by a legal system. There has been little consistency and not all that much rationality in the distinctly political process that led to the present complicated body of doctrine and procedural rules. They are, for the most part, the results of historical tradition, inertia, present value judgments about what is equitable and untested predictions about what particular substantive laws and adjective rules will accomplish.

Meckling's paper should be more disturbing than it is. Perhaps our unhappy experiences with disembodied theory have made lawyers too skeptical.

136. There might be serious problems with permitting creditors to initiate chapter XI reorganizations. It can be a threat, an in terrorem tactic. The involuntary petition can easily become a self-fulfilling prophecy. It is possible that one "unnecessary" bankruptcy can trigger others, for example, of firms dealing with the bankrupt company and of firms in the same business.

Neither do we allow one spouse to file an involuntary petition for both although he or she is apt to be the most interested and concerned party and with the best knowledge of their situation.

137. See G. Gilmore \& C. Black, The Law of Admiralty § 9-2, at 588 (1975). 
There appear to be serious problems with our system of bankruptcy law, but almost none of them have been addressed by Meckling. Instead, we are urged, in the name of science, to look at some peripheral aspects of bankruptcy law through a prism which tells us something about some economists, but very little about the problems of bankruptcy. 